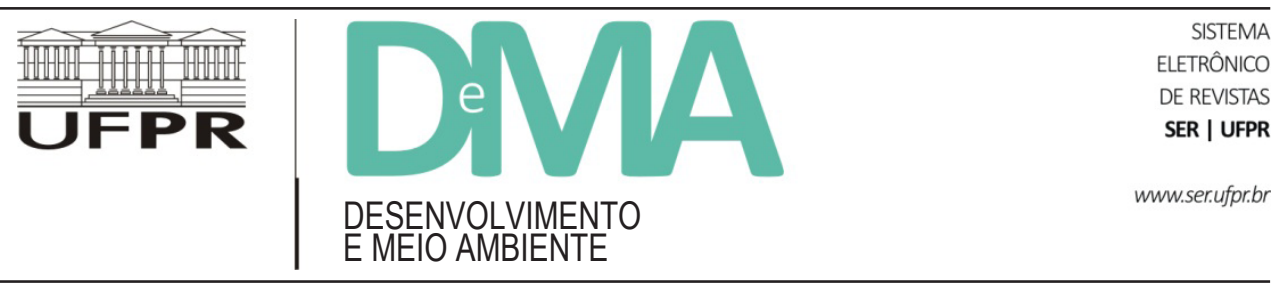

\title{
A extração da flora e fauna nativas na Amazônia brasileira - uma segunda apreciação
}

\section{Native Floral and Faunal Extraction in the Brazilian Amazon Region - a Second Look}

\author{
José Augusto DRUMMOND ${ }^{1,2^{*}}$, Claudia de SOUZA ${ }^{1}$ \\ ${ }^{1}$ Programa de Pós-Graduação em Desenvolvimento Sustentável, Universidade de Brasília (UnB), Brasília, DF, Brasil. \\ ${ }^{2}$ Centro de Desenvolvimento Sustentável, Universidade de Brasília (UnB), Brasília, DF, Brasil. \\ *E-mail de contato: jaldrummond@uol.com.br
}

Artigo recebido em 21 de agosto de 2015, versão final aceita em 25 de março de 2016.

RESUMO: Conceitua o extrativismo de baixa tecnologia, praticado em muitas partes da Amazônia brasileira. Examina 16 tópicos analíticos e conceituais recorrentes nas discussões acadêmicas e políticas sobre esse tipo de extrativismo. Avalia políticas públicas, iniciativas comunitárias, parcerias e outras formas de apoio recebidas pelos extratores. Destaca dentro de cada tópico as perspectivas de prosperidade, colapso, estagnação ou existência continuada desse modo de produzir e das populações que o praticam e dependem dele.

Palavras-chave: extrativismo; Amazônia; desenvolvimento local; reservas extrativistas; recursos da fauna; recursos da flora.

ABSTRACT: Defines low technology extraction, practiced in many parts of the Brazilian Amazon region. Examines 16 recurrent analytical and conceptual topics present in academic and political discussions about that type of extraction. Evaluates several public policies, community initiatives, partnerships and other forms of support given to extractors. Points out in each topic the perspectives of prosperity, collapse, stagnation or continued existence of low technology extraction and of the people who practice and depend on it.

Keywords: extraction; Amazon Region; local development; extractive reserves; faunal resources; floral resources.

\section{Nota sobre o texto}

Este estudo revê e atualiza um artigo publicado em 1996, com o título "A extração sustentável de produtos florestais na Amazônia brasileira”, escrito pelo primeiro autor do presente texto (Drummond, 1996).

Dois motivos nos levaram a produzir este novo texto. Em primeiro lugar, desde 1996 a temática do extrativismo amazônico mereceu uma atenção 
contínua e ampliada entre estudiosos, ativistas e formuladores de políticas. Essa atenção extravasou a região amazônica e englobou o extrativismo praticado em outros biomas e regiões do Brasil. Houve um crescimento exponencial do número de trabalhos científicos (livros, artigos, relatórios de pesquisa, textos gerados por projetos de intervenção e políticas públicas) dedicados ao extrativismo, além de inúmeros projetos e iniciativas produtivas locais, com apoio regional, nacional e internacional, mobilizando comunidades, governos estaduais, empresas, ONGs brasileiras e estrangeiras e órgãos de cooperação internacional. Surgiram ainda políticas públicas nacionais e regionais direcionadas especificamente a apoiar essa forma de atividade produtiva.

Em segundo lugar, o texto publicado em 1996 mereceu citações e comentários em muitos trabalhos e fóruns científicos; desde 2010 ele teve centenas de downloads no site pessoal do autor. Adicionalmente, vários leitores sugeriram ao autor a atualização do texto, que de fato "envelheceu" desde 1996.

Esta nova versão buscou manter ao máximo (i) o tom de discussão conceitual e analítica, (ii) a estrutura de tópicos e (iii) o formato de um ensaio, características do texto de 1996. Além disso, tivemos o cuidado de ilustrar mais fartamente diversas questões discutidas, por meio (i) de referências a fatos, processos e tendências mais recentes e (ii) da indicação de um número considerável de trabalhos de pesquisa e textos informativos produzidos mais recentemente.

\section{Introdução}

Este texto desenvolve uma discussão conceitual e analítica a respeito da viabilidade de atividades ex- trativas, principalmente em algumas partes da região amazônica brasileira e secundariamente em outras regiões do país. O principal ângulo analítico adotado na discussão é o da sustentabilidade ecológica e econômica dessas atividades. Embora seja impossível esgotar o assunto dentro do espaço de um artigo, a discussão pretende ser abrangente e sistemática. $\mathrm{O}$ texto não se baseia em resultados de um projeto de pesquisa específico dos autores sobre o assunto, mas usa argumentos e achados retirados de várias pesquisas nossas e de consultas feitas à literatura pertinente. As nossas pesquisas e a literatura consultada reúnem um grande volume de investigações (documentais e de campo) e achados originais.

Basicamente, o texto se debruça sobre as questões analíticas, conceituais, empíricas e normativas que nos parecem resumir os principais eixos temáticos pertinentes ao extrativismo. Essas questões foram colocadas em pauta para a comunidade científica desde que a militância dos seringueiros brasileiros, liderados por Francisco Alves Mendes Filho ("Chico" Mendes) (1944-1988), alcançou dimensões nacionais e internacionais e ajudou a formar um movimento - ou vários movimentos favorável a variadas formas de extrativismo.

Depois do colapso do ciclo extrativista da borracha amazônica, ocorrido pouco depois de 1910, o extrativismo amazônico - como prática produtiva e como tema de estudos - passou cerca de 80 anos em estado de dormência. O tema ressurgiu no Brasil nos anos 1980 como um dos vários tópicos de um debate muito mais amplo sobre os usos e o destino das florestas amazônicas. Esse ressurgimento acabou chamando a atenção também para atividades extrativistas praticadas em outros biomas brasileiros. $\mathrm{O}$ extrativismo voltou à pauta regional amazônica, com apoio de um movimento ambientalista mundial fortemente influenciado por cientistas e militantes 
dos países desenvolvidos. Esse movimento abriu uma nova frente de críticas contra práticas e políticas (expansão de pastagens, incentivos à migração, desmatamento, mineração, construção de estradas e hidrelétricas, etc.) consideradas ameaçadoras à integridade das florestas tropicais úmidas de todo o mundo, e do Brasil em particular, e a favor de atividades que levem em consideração a integridade das florestas da região (Moran, 1981; 1990; Myers, 1983; 1985; Foresta, 1991; Schmink \& Wood, 1984; 1992; Hecht, 1989; Uhl \& Vieira, 1989; Posey \& Balee, 1989; Anderson, 1990; Anderson et al., 1994; Kitamura, 1994; Uhl et al., 1997; Drummond, 2000; Veríssimo et al., 2002).

No complexo emaranhado de questões econômicas, ecológicas, políticas e culturais em debate, os seringueiros brasileiros, cuja visibilidade na própria região amazônica foi inexpressiva mesmo durante o boom da borracha, reapareceram na década de 1980 com uma nova identidade: a de "ambientalistas". Eles souberam ligar os requisitos da sua sobrevivência enquanto grupo social e profissional de extratores às vantagens proclamadas do seu uso predominantemente extrativo das florestas amazônicas - mais objetivamente, souberam destacar que esse tipo de uso não implica em desmatamento. Com a formulação do conceito econômico, fundiário, legal e comunitário das "reservas extrativistas", para a qual concorreram cientistas e gestores como Mary Allegretti (1987), Alfredo Wagner Berno de Almeida, Manuela Carneiro da Cunha, Stephan Schwartzman, Mauro Almeida e Mario Menezes, entre outros, o tema do extrativismo amazônico emergiu de um ostracismo quase secular. Desde o assassinato de Chico Mendes, em dezembro de 1988, o tema ocupou lugar destacado no palco das amplas discussões contemporâneas sobre o destino das florestas amazônicas e das florestas tropicais úmidas em geral.

\section{A visibilidade crescente do extrativismo}

Uma das dimensões em que a questão do extrativismo ganhou impulso e visibilidade foi a da criação/proteção de áreas propícias à continuidade do extrativismo e à permanência das populações extrativistas residentes nessas áreas. Vejamos algumas expressões disso. Em 1985, o Primeiro Encontro Nacional dos Seringueiros, realizado no campus da Universidade de Brasília, reuniu seringueiros da Amazônia, deu origem ao Conselho Nacional dos Seringueiros (CNS) e lançou o conceito de reservas extrativistas (RESEX). As RESEXs lhes garantiriam o uso das suas terras e dos recursos naturais conexos. Representariam uma nova e original modalidade de regularização de direitos fundiários (na forma de apropriação coletiva), de proteção de territórios e de apoio ao uso extrativista dos recursos naturais. Seringueiros, ribeirinhos, pescadores artesanais, castanheiros, quebradeiras de coco de babaçu e outros extratores acabaram se apropriando do conceito, pois têm em comum o fato de depender fortemente da extração de recursos naturais (encontrados em lagos, florestas, rios, mar, litorais etc.) para obter a sua subsistência (Porto-Gonçalves, 2000; Allegretti, 2008).

Adicionalmente, a postura "ambientalista" dos seringueiros brasileiros ganhou ampla simpatia ou o apoio ativo de muitos cientistas e técnicos e de ambientalistas brasileiros, de alguns políticos regionais e setores governamentais, além de ambientalistas estrangeiros e até de técnicos de bancos multilaterais. Eis os nomes de apenas alguns deles: Marina Silva, os irmãos Tião e Jorge Vianna, João Capiberibe, Mauro W. B. Almeida, Ricardo Arnt, Adalberto Veríssimo, Gilney Viana, João Paulo Ribeiro Capobianco, Susana Hecht, Alexander Cockburn, Anthony Anderson, Roger Stone, Paul 
Little e Lia Osório Machado. Essa postura ambientalista e a própria viabilidade econômica do extrativismo mereceram também uma boa dose de críticas feitas por outros cientistas brasileiros, particularmente por Alfredo Homma (Homma, 1993), além de governantes locais, representantes de interesses de outros segmentos sociais (agricultores, pecuaristas, madeireiros, seringalistas, pescadores comerciais, etc.).

A primeira solução institucional construída pelo governo brasileiro para apoiar as comunidades extrativistas ocorreu em 1993: a criação, pelo INCRA, dos "projetos de assentamentos extrativistas" - PAEs. ${ }^{1}$ Esses assentamentos se destinavam "à exploração de áreas dotadas de seringais extrativos através de atividades economicamente viáveis e ecologicamente sustentáveis, a serem executadas pelas populações que ocupam ou venham a ocupar as mencionadas áreas". A portaria estabelecia que o uso da área ocorreria "mediante concessão de uso em regime comunal, segundo a forma decidida pela comunidade concessionária - associativa, condominial ou cooperativista". Em 1996, o INCRA substituiu a expressão "Projeto de Assentamento Extrativista" por "Projeto de Assentamento Agroextrativista", embora o órgão tenha continuado a usar a sigla PAE. ${ }^{2}$ Até abril de 2014 foram criados 398 PAEs, beneficiando 97.323 famílias (cerca de 500.000 pessoas) e abrangendo 9.764.210 hectares, distribuídos por seis estados - Pará, Amazonas, Acre, Amapá, Maranhão e Minas Gerais.
Mais tarde, o INCRA criou duas outras modalidades de assentamentos de apoio ao extrativismo, principalmente para atender às reivindicações dos extratores da Amazônia: Projetos de Desenvolvimento Sustentável (PDSs) ${ }^{3}$ e Projetos de Assentamento Florestal (PAFs). ${ }^{4}$ Os PDSs foram criados para sediar atividades "ambientalmente diferenciadas" por populações tradicionais (ribeirinhos, comunidades extrativistas, etc.). Em fins de 2014 existiam 128 PDSs no Brasil, distribuídos em 14 unidades da federação - Acre, Amazonas, Rondônia, Amapá, Sergipe, Piauí, Pernambuco, Bahia, Rio de Janeiro, São Paulo, Maranhão, Mato Grosso, Distrito Federal e Pará, beneficiando 24.786 famílias (cerca de 125.000 pessoas) e cobrindo uma área de 3.270 .483 hectares.

Os PAFs foram criados em áreas com aptidão para o manejo florestal de uso múltiplo, em base familiar comunitária e sustentável. As áreas são administradas pelas associações ou cooperativas dos produtores assentados, as quais recebem "termos de concessão de uso". Esse tipo de assentamento prevê ainda a formação de plantios de espécies da flora nativa, nos casos de haver áreas significativas convertidas para outras atividades produtivas. Até 2014 foram criados sete PAFs, beneficiando 1.164 famílias (cerca de 6.000 pessoas) e ocupando uma área de 312.032 hectares - quatro no Acre, duas no Amazonas e uma em Rondônia.

As Tabelas 1 e 2 resumem cifras e outros dados referentes a esses três formatos de estímulo e apoio ao extrativismo.

\footnotetext{
1 Portaria n. 812 da MAARA, 16 de dezembro de 1993.

2 Portaria INCRA/P n ${ }^{\circ}$ 268, de 23 de outubro de 1996; Portaria INCRA/P n ${ }^{\circ}$ 269, de 23 de outubro de 1996.

3 Portaria Interministerial MMA/MDA n ${ }^{\circ}$, de 24 de setembro de 1999; Portaria INCRA n ${ }^{\circ} 477$, de 4 de novembro de 1999; Portaria INCRA/P $n^{\circ} 1.032$, de 25 de outubro de 2000; Norma de Execução INCRA n ${ }^{\circ}$ 69, de 12 de março de 2008; Norma de Execução INCRA nº 87, de 26 de novembro de 2009. Disponíveis em: <http://www.incra.gov.br/assentamentoscriacao>. Acesso em: 08 mar. 2015.

${ }^{4}$ Portaria INCRA n $^{\circ}$ 1.141, de 19 de dezembro de 2003; Portaria INCRA/P n ${ }^{\circ} 215$, de 6 de junho de 2006; Norma de Execução INCRA n ${ }^{\circ}$ 69, de 12 de março de 2008; Norma de Execução INCRA n ${ }^{\circ}$ 87, de 26 de novembro de 2009. Disponível em: <http://www.incra.gov.br/assentamentoscriacao>. Acesso em: 08 mar. 2015.
} 
TABELA 1 - Tipos de assentamentos de apoio ao extrativismo criados pelo INCRA, até outubro de 2014 - dados diversos.

\begin{tabular}{lcccc}
\hline \multicolumn{1}{c}{ Categoria } & $\begin{array}{c}\text { Unidades } \\
\text { (número) }\end{array}$ & $\begin{array}{c}\text { Famílias } \\
\text { assentadas } \\
\text { (número) }\end{array}$ & $\begin{array}{c}\text { Capacidade dos } \\
\text { assentamentos (em número } \\
\text { de famílias) }\end{array}$ & $\begin{array}{c}\text { Área } \\
\text { (ha) }\end{array}$ \\
\hline $\begin{array}{l}\text { Projetos de Assentamento } \\
\text { Agroextrativista (PAEs) }\end{array}$ & 398 & 97.323 & 110.471 & 9.764 .210 \\
$\begin{array}{l}\text { Projetos de Assentamento Florestal } \\
\text { (PAFs) }\end{array}$ & 7 & 1.164 & 1.507 & 312.032 \\
$\begin{array}{l}\text { Projetos de Desenvolvimento } \\
\text { Sustentável (PDSs) }\end{array}$ & 128 & 24.786 & 31.145 & 3.270 .483 \\
Total & $\mathbf{5 3 3}$ & $\mathbf{1 2 3 . 2 7 3}$ & $\mathbf{1 4 3 . 1 2 3}$ & $\mathbf{1 3 . 3 4 6 . 7 2 5}$ \\
\hline
\end{tabular}

FONTE: INCRA (2014).

TABELA 2 - Tipos de assentamentos de apoio ao extrativismo criados pelo INCRA - distribuição por Estados, até outubro de 2014.

\begin{tabular}{|c|c|c|c|c|c|c|c|c|c|c|c|c|c|c|c|c|}
\hline \multirow{2}{*}{ Categoria } & \multirow{2}{*}{$\begin{array}{l}\text { Unidades } \\
\text { (número } \\
\text { total) }\end{array}$} & \multicolumn{15}{|c|}{ Estado } \\
\hline & & PA & AM & $\mathrm{AC}$ & $\mathbf{A P}$ & RO & MT & PI & MA & RJ & PE & SE & BA & MG & DF & SP \\
\hline $\begin{array}{c}\text { Projetos de } \\
\text { Assentamento } \\
\text { Agroextrativista }\end{array}$ & 398 & 316 & 49 & 13 & 12 & - & - & - & 7 & - & - & - & - & 1 & - & - \\
\hline $\begin{array}{l}\text { Projetos de } \\
\text { Assentamento } \\
\text { Florestal }\end{array}$ & 7 & - & 2 & 4 & - & 1 & - & - & - & - & - & - & - & - & - & - \\
\hline $\begin{array}{c}\text { Projetos de } \\
\text { Desenvolvimento } \\
\text { Sustentável }\end{array}$ & 128 & 37 & 20 & 22 & 1 & 4 & 12 & 2 & 7 & 1 & 1 & 1 & 1 & - & 1 & 18 \\
\hline Total & 533 & 353 & 71 & 39 & 13 & 5 & 12 & 2 & 14 & 1 & 1 & 1 & 1 & 1 & 1 & 18 \\
\hline
\end{tabular}

FONTE: INCRA (2014).

No entanto, o formato institucional mais conhecido de apoio ao extrativismo é o das reservas extrativistas - RESEXs. Elas foram definidas desde a década de 1980 por diversos instrumentos administrativos e legais e acabaram sendo classificadas como unidades de conservação de uso sustentável, dentro da classificação definida pela lei do SNUC (Lei n. 9.985, de 18 de julho de 2000). Até outubro de 2014, foram criadas no Brasil 90 reservas extrativistas federais e estaduais, com uma área conjunta de 14.457 .000 ha, beneficiando um número indeterminado de pessoas, mas que deve chegar às várias dezenas de milhares (ver Tabelas 3 e 4). Um outro formato de unidade de conservação capaz de apoiar o extrativismo, também previsto na lei do SNUC, é o das reservas de desenvolvimento sustentável - RDSs. Em fins de 2014, existiam 36 RDSs, com uma área conjunta de 11.129.300 ha, conforme os dados da Tabela 3.

As cifras que constam das Tabela 3 e 4 mostram que esses cinco tipos de áreas designadas para práticas extrativistas são numerosas, ocupam uma área nada desprezível das áreas de florestas tropicais e de diversos outros ecossistemas e beneficiaram um contingente razoável de pessoas, estimável em pelo menos 700.000. Em cerca de 20 anos de 
TABELA 3 - Reservas extrativistas e reservas de desenvolvimento sustentável existentes no Brasil: números e áreas ocupadas, outubro de 2014.

\begin{tabular}{lcc}
\hline \multicolumn{1}{c}{ Categoria } & Unidades (número) & Área total (ha) \\
\hline Reservas Extrativistas federais & 62 & 12.436 .200 \\
Reservas Extrativistas estaduais & 28 & 2.020 .800 \\
Total de Reservas Extrativistas (i) & $\mathbf{9 0}$ & $\mathbf{1 4 . 4 5 7 . 0 0 0}$ \\
Reservas de Desenvolvimento Sustentável federais & 2 & 102.600 \\
Reservas de Desenvolvimento Sustentável estaduais & 29 & 11.009 .000 \\
Reservas de Desenvolvimento Sustentável municipais & 5 & 17.600 \\
Total de Reservas de Desenvolvimento Sustentável (ii) & $\mathbf{3 6}$ & $\mathbf{1 1 . 1 2 9 . 3 0 0}$ \\
Total geral (i + ii) & $\mathbf{1 2 6}$ & $\mathbf{2 5 . 5 8 6 . 3 0 0}$ \\
\hline
\end{tabular}

FONTE: CNUC/MMA - Tabela consolidada das unidades de conservação. Disponível em: <www.mma.gov.br/cadastro_uc>. Atualizada em: 27 de outubro de 2014. Acesso em: 10 mar. 2015.

TABELA 4 - Reservas extrativistas e reservas de desenvolvimento sustentável existentes no Brasil: distribuição por Estado, outubro de 2014.

\begin{tabular}{|c|c|c|c|c|c|c|c|c|c|c|c|c|c|c|c|c|c|}
\hline \multirow{2}{*}{ Categoria } & \multirow{2}{*}{$\begin{array}{l}\text { Unidades } \\
\text { (número } \\
\text { total) }\end{array}$} & \multicolumn{16}{|c|}{ Estado } \\
\hline & & PA & $\mathbf{A M}$ & $\mathbf{A C}$ & $\mathbf{A P}$ & RO & CE & MT & MA & RJ & PE & ES & BA & MG & RN & SP & SC \\
\hline $\begin{array}{l}\text { Reservas Extrativistas } \\
\text { Federais }\end{array}$ & 62 & 15 & 12 & 5 & 1 & 21 & 2 & - & 2 & - & 1 & - & 3 & - & - & - & - \\
\hline $\begin{array}{l}\text { Reservas Extrativistas } \\
\text { Estaduais }\end{array}$ & 28 & - & 4 & - & - & 21 & - & 1 & - & - & - & - & - & - & - & 2 & - \\
\hline $\begin{array}{l}\text { Reservas de } \\
\text { Desenvolvimento } \\
\text { Sustentável Federais }\end{array}$ & 2 & 1 & - & - & - & - & - & - & - & - & - & - & - & 1 & - & - & - \\
\hline $\begin{array}{l}\text { Reservas de } \\
\text { Desenvolvimento } \\
\text { Sustentável Estaduais }\end{array}$ & 29 & 2 & 15 & - & 1 & - & - & - & - & 1 & - & 1 & - & 1 & 1 & 7 & - \\
\hline $\begin{array}{l}\text { Reservas de } \\
\text { Desenvolvimento } \\
\text { Sustentável Municipais }\end{array}$ & 5 & - & 1 & - & - & - & - & - & - & - & - & 3 & - & - & - & - & 1 \\
\hline Total & 126 & 18 & 33 & 5 & 2 & 42 & 2 & 1 & 2 & 1 & 1 & 4 & 3 & 2 & 1 & 9 & 1 \\
\hline
\end{tabular}

FONTE: CNUC/MMA - Tabela consolidada das unidades de conservação. Disponível em: <www.mma.gov.br/cadastro_uc>. Atualizada em: 27 de outubro de 2014. Acesso em: 10 mar. 2015.

existência do conjunto dessas áreas, foram criadas 659 unidades das cinco modalidades - cerca de 27 por ano, mais de duas por mês.

Em fins de 2014, essas 659 unidades de apoio ao extrativismo (126 RESEXs e RDSs sob responsabilidade do ICMBio e 533 unidades geridas pelo INCRA) ocupavam conjuntamente uma área de 38.933.025 hectares $(25.586 .300+13.346 .725)$. Isso representa cerca de $4,5 \%$ do território nacional, cifra nada desprezível que corresponde a cerca da metade de toda a área agrícola atualmente cultivada comercialmente no Brasil. Outro dado expressivo é a vasta distribuição geográfica dessas unidades: as cinco modalidades afetam diferenciadamente áreas 
dos territórios do Pará, Amazonas, Acre, Amapá, Rondônia, Ceará, Mato Grosso, Maranhão, Rio de Janeiro, Pernambuco, Espírito Santo, Bahia, Minas Gerais, Rio Grande do Norte, São Paulo, Santa Catarina, Piauí, Sergipe e Distrito Federal - uma marca impressionante de 18 Estados e o Distrito Federal. Pará é o Estado com maior número de unidades 371. Em seguida vêm Amazonas (104), Rondônia (47), Acre (44), São Paulo (18), Maranhão (16) e Amapá (15). Como se vê, o perfil dessa distribuição favorece fortemente a Região Norte, ou a Amazônia Legal (se incluirmos os dados sobre o Maranhão), o que é coerente com o local de "nascimento" das RESEXs e dos PAEs.

Um exemplo notável de apoio institucional obtido pelas reservas extrativistas foi a criação de um projeto específico (Projeto RESEX) no âmbito do Programa Piloto do G7 de Proteção das Florestas Tropicais do Brasil - PP-G7. O PP-G7 foi uma iniciativa conjunta dos sete países mais industrializados (G7), Países Baixos, Banco Mundial e governo brasileiro, que assumiram o compromisso de financiar uma série de projetos visando à proteção daquelas florestas - apoio a áreas protegidas e a reservas extrativistas, melhora dos órgãos ambientais estaduais, investimentos diretos em projetos demonstrativos, etc. O PP-G7 foi aprovado em 1990, a sua execução começou em 1994 e chegou ao fim em 2009. Teve como principais resultados relativos às RESEXs a consolidação de 2,1 milhões de hectares de reservas extrativistas e investimentos específicos em quatro delas: Alto Juruá (Acre), Chico Mendes (Acre), Rio Ouro Preto (Rondônia) e Rio Cajari (Amapá) (De Antoni, 2010).

O debate em torno da viabilidade do extrativismo amazônico teve o mérito de estimular uma ampla discussão - tanto técnica quanto política (e apaixonada) - sobre os muitos usos registrados e potenciais dos recursos florestais e não florestais da Amazônia (Anderson, 1990; Drummond, 1998; 2000; 2013). O assassinato de Chico Mendes fortaleceu o tom apaixonado de um debate que já corria com aspereza. Assim, o tema do extrativismo ajudou a despertar uma ampla reflexão sobre as perspectivas e os potenciais do uso das terras e dos recursos da Amazônia e de outras terras florestadas dos trópicos. Essa discussão acabou incluindo outros biomas brasileiros nos quais também existem atividades extrativistas.

Levando em conta essas mudanças - o forte crescimento do apoio institucionalizado ao extrativismo, a discussão ampliada sobre ele, a maior visibilidade por ele alcançada e pelas políticas públicas conexas -, o presente texto foi construído de forma a tratar de uma grande variedade de tópicos. Depois desta introdução, dedicamos uma seção a propor uma definição de trabalho de extrativismo. Na seção seguinte, conceituamos o tipo de extrativismo que abordamos no resto do artigo. Depois abordamos 16 principais tópicos do debate sobre o extrativismo amazônico (e secundariamente atividades extrativistas de outras regiões). Esses tópicos são tratados separadamente, um a um, na medida do possível. O texto conclui com uma seção que apresenta considerações sobre a viabilidade e a "desejabilidade" da existência de um setor extrativista com bases comunitárias e ecologicamente sustentáveis na Amazônia brasileira e em outras regiões.

\section{Uma definição de extrativismo}

O extrativismo - ou uma economia extrativista ou extrativa - é, no sentido mais básico, uma maneira de produzir bens na qual grupos humanos retiram recursos naturais úteis diretamente da sua área de ocorrência natural. Ele se distingue de - e contrasta 
com - todas as demais formas de produção, como a agricultura, o pastoreio, o comércio, o artesanato, os serviços e as indústrias de todos os tipos.

A caça, a pesca e a coleta de produtos vegetais são os três exemplos clássicos de atividades extrativas. Várias formas de combinação dessas três atividades sustentaram, com exclusividade, um número desconhecido de sociedades humanas, por pelo menos muitas dezenas de milhares de anos. Em tempos mais recentes, essas atividades por vezes se combinaram com diversas formas de manejo de flora e fauna, precursoras da agricultura e da pecuária propriamente ditas. As atividades extrativas só deixaram de ser decisivas para a sobrevivência dos humanos - embora sem desaparecer - com o surgimento da agricultura e da pecuária permanentes, que a literatura arqueológica, histórica e antropológica associa à revolução neolítica. Essa revolução ocorreu há apenas poucos milhares de anos, apenas em alguns poucos lugares, espalhando-se ao longo de milênios para outros lugares (Bellwood, 2005; Mazoyer \& Rodart, 2010). Se por um longo período todos os humanos dependeram totalmente do extrativismo, a invenção e o espalhamento da agricultura e da pecuária reduziram drasticamente a dependência humana da extração. Conforme a sociedade humana, global ou local, foi dependendo cada vez mais da agropecuária, a proporção de humanos dedicada à extração caiu vertiginosamente.

Quase toda a tecnologia empregada nas atividades extrativistas era e é "elementar", simbólica ou empiricamente: não havia ou nem há necessidade de complexas mediações tecnológicas, científicas ou mecânicas entre os extratores e os recursos naturais. Chamaremos essa modalidade de extrativismo de baixa tecnologia. Quando esse extrativismo forma a base exclusiva ou quase exclusiva de sustento de um grupo humano, ela se associa a um tipo de sociedade - "povos pré-históricos", "bandos", "comunidades primitivas", "tribos", "povos pré-modernos", etc. - muito familiar aos antropólogos clássicos e a alguns antropólogos contemporâneos. Esse tipo de sociedade tem, via de regra, pequena dimensão populacional, lento crescimento demográfico, baixa densidade demográfica, é nômade, exibe pouca divisão de trabalho entre grupos sociais e carece de formas centralizadas de governo. As três atividades extrativas - caça, pesca e coleta vegetal sobreviveram mesmo em sociedades que adotaram formas rudimentares ou itinerantes de agricultura ou de pecuária, complementando os recursos de subsistência, principalmente com alimentos de origem animal e vegetal cujo cultivo era inviável ou desconhecido.

Em algumas sociedades contemporâneas, como a brasileira e a de Papua Nova Guiné, ainda há grupos sociais demográfica e culturalmente expressivos que se engajam nessas atividades extrativistas, em caráter exclusivo ou parcial, como práticas cotidianas de sobrevivência. Nessas mesmas sociedades há, no entanto, outros segmentos sociais que se dedicam exclusivamente a atividades agrícolas, pastoris, comerciais, artesanais, de serviços ou industriais. Nesses casos, a produção extrativista é tipicamente ligada à subsistência, embora possa conviver com a produção de excedentes para o mercado. Isso mostra que os extrativistas de hoje em dia podem se engajar em atividades extrativistas que não sejam exclusivamente de subsistência. Em outras sociedades, tal como nos principais países desenvolvidos, as práticas e as populações extrativistas (conforme definidas aqui) praticamente desapareceram (a não ser em áreas muito isoladas ou remotas). Em muitos lugares, práticas extrativistas (como algumas formas de caça e pesca) se 
transformaram em atividades de lazer para grupos sociais não extrativistas.

No entanto, o termo extrativismo e extração são comumente aplicados também a atividades francamente "modernas", próprias de era industrial e dos empreendimentos produtivos de grande escala. Nelas, alguns materiais naturais também são retirados do seu local de ocorrência, mas com a intermediação de tecnologia e maquinário complexos ou sofisticados e com destinação exclusiva para o mercado. Referimo-nos, entre outros, à mineração de grande escala, à extração de petróleo e gás natural e ao corte de árvores em grande escala. Podemos incluir as grandes obras de manipulação da água (aquedutos, represas, barragens, transposições, irrigação). Nesses casos, no entanto, o extrativismo não caracteriza as sociedades como um todo, e sim certos setores produtivos de sociedades complexas dotadas de agricultura, pecuária, comércio, artesanato, indústria transformativa e serviços. Esses setores extrativistas modernos (por exemplo, mineração, exploração petrolífera, madeireiras), que chamamos aqui de extrativistas de alta tecnologia, exigem investimentos elevados; esses investimentos têm longos prazos de maturação, demandam mão de obra com alta qualificação formal e estão ligados a mercados dinâmicos de commodities (em escala nacional ou mesmo global) que não deixam espaço para a produção de pequena escala e com base em tecnologias simples.

Mesmo em países como o Brasil, dotado de uma economia fortemente baseada na agropecuária, na indústria e nos serviços, o extrativismo de baixa tecnologia é tipicamente uma atividade importante apenas em áreas "remotas" ou de "fronteira" (onde tecnologia, capitais, mão de obra qualificada e infraestrutura são escassos). Nesse extrativismo, um número relativamente pequeno de trabalhadores, com pouca qualificação formal, pobremente equipados, "arranca à unha" alguns recursos da natureza, num ambiente de pouco investimento de capital e de baixos retornos produtivos e financeiros para os produtores diretos. O extrativismo de alta tecnologia pode ou não ocorrer nessas mesmas regiões, em busca dos mesmos recursos ou em busca de outros recursos. Mas, quando ele se instala nessas regiões, via de regra ele desloca os extratores locais e a sua produção e introduz "modernizações" tecnológicas e mecânicas compatíveis apenas com grandes escalas comerciais de produção, determinadas pela competição em mercados de escala nacional ou internacional. Essas tecnologias são pesadas/ sofisticadas, exigem investimentos de vulto, os trabalhadores são em geral bem pagos e têm alta qualificação formal, e os retornos produtivos e financeiros são altos.

O extrativismo de baixa tecnologia pode conviver com o de alta tecnologia numa mesma sociedade, inclusive numa mesma região e até num mesmo ramo de atividade, como uma forma "tradicional" de produzir que sobrevive à "modernização" ou quando o bem natural perde - por motivos que não é preciso discutir aqui - valor econômico de mercado. O garimpo manual ou pouco mecanizado, por exemplo, pode operar ao mesmo tempo e no mesmo lugar que uma empresa mineradora capitalizada, mas apenas se o mineral tiver alto valor por unidade de volume, como o ouro ou as pedras preciosas. O mesmo não ocorre com a produção de minérios de ferro, alumínio e manganês, 
por exemplo, que têm baixo valor por unidade de volume, o que significa que a lucratividade depende da produção de grandes volumes.

Outro exemplo: depois do colapso comercial da borracha extraída na Amazônia, nos anos 1910, os seringueiros brasileiros, por causa de subsídios e de reservas de mercado instituídos no Brasil, continuaram a produzir de forma extrativista quantidades mais baixas de borracha mais cara e de qualidade menor, competindo no mercado interno brasileiro com a borracha importada oriunda das plantações em escala industrial de seringueiras (isto é, a sua exploração em grandes plantations) em outros países. Essa co-ocorrência dos dois tipos de extrativismos é muito mais rara ou mesmo impossível nos casos de outros bens econômicos, como o petróleo e o gás natural que, além de terem preço baixo por unidade de volume, exigem investimentos de alto porte que encarecem os custos de extração e processamento. Isso tudo exclui o extrator de baixa tecnologia.

Para efeito do presente texto, o extrativismo que interessa é o de baixa tecnologia, focalizado em produtos vegetais e animais do bioma Amazônia e secundariamente de outros biomas. Demos atenção especial a processos e fatos que ocorrem dentro de reservas extrativistas e áreas similares, já que elas expressam simultaneamente a existência de comunidades dependentes/praticantes do extrativismo e um conjunto de políticas públicas de estímulo ao extrativismo. Essas comunidades extrativistas, amazônicas ou não, praticam modos de extração de flora (e, em menor número, de fauna) que não dependem de grandes insumos de capital e tecnologia.

Isso não impede, no entanto, a possibilidade de que formas mais "modernas" de extrair esses mesmos bens venham a surgir a curto prazo, dentro e fora dessas unidades, por iniciativa das próprias comunidades extrativistas ou de outros atores sociais. Um exemplo que será mencionado mais à frente é o do plantio de castanheiras, que faz com que parte dos volumes desse produto secularmente extrativista sejam agora oriundos de plantações.

Outro detalhe distintivo dessas unidades extrativistas é que elas se dedicam tipicamente a produzir bens conceituados como "renováveis" (basicamente plantas e animais ou gerados por plantas e animais), ou seja, bens cujos estoques são repostos por processos naturais numa escala de tempo compatível com a cultura humana e os processos sociais conexos. Ou seja, essas comunidades não têm se dedicado à mineração ou à extração de petróleo e gás natural e outros recursos naturais finitos ou "não renováveis".

Essa capacidade de renovação natural dos estoques é crucial para o próprio conceito de reservas ou comunidades extrativistas. É ela que garante conceitualmente (e talvez em termos práticos) que haja uma produção contínua ou estável de bens (que os cientistas de língua inglesa chamam de sustained yield), comumente chamada em português de produção sustentável. É esse tipo de produção que pode garantir em longo prazo os meios de subsistência para os extratores.

Outra dimensão relevante do conceito de extrativismo adotado aqui é a tendência de as economias extrativistas (quando voltadas para o mercado e não para a subsistência) se concentrarem em um ou dois bens cujo valor de mercado é sujeito a alterações bruscas. Esse arranjo é tipicamente instável, causando ciclos voláteis de prosperidade e falência. Não se trata apenas do fato comum de as comunidades dependerem excessivamente de um único bem, ou do fato igualmente comum de os preços desse bem variarem bruscamente; é relevante também que esse bem seja, via de regra, exportado da região produtora sem quaisquer trans- 
formações ou processamentos industriais, ou apenas com as transformações estritamente necessárias para a preservação de suas características naturais. Assim, uma economia extrativa, por definição, não processa localmente os bens que retira da natureza ou os processa apenas preliminarmente (Bunker, 1984; 1985; Drummond, 2002).

Isso significa transferir para outras regiões e outros grupos sociais - ou mesmo para outros países - os valores agregados ligados ao processamento secundário, à transformação industrial, à comercialização no atacado e no varejo, ao marketing, ao transporte, etc. dos produtos intermediários e finais. Processos sociais gerados por essas outras etapas produtivas - como a diversificação de unidades produtivas, a formação de outros grupos sociais, a maior qualificação dos trabalhadores, a elevação do nível de renda dos trabalhadores, o desenvolvimento tecnológico e o surgimento das atividades secundárias e terciárias - ocorrem de forma muito superficial ou não ocorrem em regiões extrativas. As economias extrativistas por definição se situam no início das cadeias produtivas e por causa disso não têm controle sobre - nem se beneficiam - as demais etapas dessas cadeias.

A cadeia produtiva é uma sequência de operações que conduzem ao processamento e à finalização de bens (Afonso, 2012). Ela reúne diferentes agentes, cada qual buscando assegurar a sua própria existência e melhoria. As tecnologias e a maximização de lucros influenciam a formação das cadeias. Vejamos uma ilustração disso pertinente ao extrativismo. As cadeias produtivas de produtos florestais não madeireiros são consideradas longas. São compostas, em geral, por quatro atores distintos: (i) o patrão, que se apropria de terras e bens e arregimenta a mão de obra necessária; (ii) o extrator, que é o morador local que coleta a matéria-prima, em tempo integral ou parcial; (iii) o intermediário, geralmente envolvido no transporte dos bens coletados e que pode ou não ser subordinado aos patrões; e (iv) o atacadista, que compra os produtos e os vende nos mercados externo e interno, com ou sem processamento (Gonçalo, 2006; Afonso, 2008, p. 21). No caso dos produtos madeireiros, outros elos podem ser somados à cadeia: as serrarias e indústrias de movelaria, os designers de móveis e os varejistas. É evidente que o extrator é apenas um elo da cadeia, exatamente o elo que tende a ser o mais frágil.

As reservas extrativistas da Amazônia e de outros biomas foram criadas com o ideal de produzir um fluxo contínuo de bens naturais, coletados com pouco ou nenhum investimento tecnológico, para serem transportados, transformados, "marketeados", comercializados e consumidos localmente ou em outras regiões e países. Por vezes, algum processamento dos bens extraídos pela baixa tecnologia ocorre localmente, mas a sua contribuição para a formação do preço final dos produtos derivados é, via de regra, mínima. Assim, o extrator atua apenas no ato inicial da formação da cadeia, "à montante" dela, e é remunerado exclusivamente por essa participação. Não recebe nem tem qualquer controle sobre a remuneração dos diversos atores produtivos que intervêm "a jusante" da cadeia. Essa estrutura de remunerações distintas pagas a atores distintos e de formação de preços dos produtos intermediários e finais não é alterada pela existência de "territórios extrativistas".

Não é demais lembrar que os trabalhadores extrativistas produzem também (via caça, pesca, coleta, artesanato e até agricultura e pecuária) "valores de uso", ou seja, bens consumíveis diretamente por eles mesmos ou que ingressam em esquemas de escambos locais. No entanto, não é o eventual 
caráter de subsistência das reservas extrativistas que tem despertado mais atenção e maior controvérsia, e sim as suas possibilidades de produzir valores de troca a serem negociados em mercados regionais, nacionais e internacionais.

Para completar o quadro conceitual pertinente às atividades e às reservas extrativistas, pode-se admitir que elas desenvolvam alguma criação animal (de espécies nativas ou exóticas) e algum cultivo de plantas (idem), desde que os valores dos bens assim produzidos não superem o valor dos bens extraídos.

Ampliando a reflexão sobre essa questão de remunerações "extras" recebidas por extratores para além do seu extrativismo, recentemente vem ganhando destaque uma outra maneira pela qual podem ser amenizadas as dificuldades inerentes do extrativismo no mundo moderno - trata-se do chamado pagamento por serviços ambientais. Esse é um instrumento que remunera ou recompensa diretamente os produtores - não necessariamente apenas extratores - pelo seu papel de proteger os recursos naturais, em especial a cobertura florestal e recursos conexos a ela (como a água). Ele estimula a conservação, mesmo em situações de exploração de florestas, desde que conduzida de forma mais racional. Ele contribui ainda para a reprodução social das populações extrativistas, via distribuição mais equitativa de renda, principalmente quando se trata de famílias que vivem em condições de subsistência (Negret, 2008; Maciel et al., 2010; Eloy et al., 2013).

Atividades como a extração da borracha $(\mathrm{He}$ vea brasiliensis) e da castanha-do-Brasil (Bertholetia excelsa Kunth) têm um peso mínimo nos fluxos financeiros da economia brasileira contemporânea e mesmo dentro da economia regional amazônica. Como o valor dos serviços ambientais não é incorporado à renda oriunda do extrativismo vegetal tradicional, o retorno financeiro pago aos extratores pelos seus serviços ambientais é sistematicamente baixo (Fearnside, 1989; Maciel et al., 2010). Já existem no Brasil alguns mecanismos estaduais de compensação por serviços ambientais, como o do Estado do Acre (Lei Estadual 1.277/99, chamada de "Lei Chico Mendes"), que em 1999 repassava um subsídio de R $\$ 0,70$ (setenta centavos de real) por quilo de borracha comercializada (Silva \& Teixeira, 2004). No Estado do Amazonas há desde 2007 o programa "Bolsa-Floresta" (Lei Estadual $3.135 / 2007$ ), que instituiu o pagamento por serviços e produtos ambientais às comunidades que utilizam de forma sustentável, conservam e protegem a biodiversidade, incluindo aquelas que se comprometem voluntariamente com a redução do desmatamento. ${ }^{5}$ A Costa Rica vem se destacando no panorama mundial da proteção ao meio ambiente $\mathrm{e}$ aos recursos naturais por ter adotado um mecanismo de gestão que remunera diretamente proprietários rurais por cada hectare de floresta protegido, embora o programa se aplique principalmente a grandes, médios e pequenos fazendeiros e pecuaristas, e não a extratores (Fearnside, 1989; Peters et al., 1989; Silva \& Teixeira, 2004; Silva \& Silva, 2006; Maciel et al., 2010; Fonseca \& Drummond, 2015).

Colocadas essas definições e considerações analíticas, passamos na seção seguinte a discutir vários tópicos recorrentes nas discussões sobre a viabilidade da produção continuada de recursos naturais em modo extrativista.

\footnotetext{
5 Lei 3.135, sobre Mudanças Climáticas, Conservação Ambiental e Desenvolvimento Sustentável do Amazonas. Disponível em: <http://www. sefaz.am.gov.br/Areas/OpcaoSistemas/SILT/Normas/Legisla\%E7\%E3o\%20Estadual/Lei\%20Estadual/Ano\%202007/Arquivo/LE\%203135\%20 07.htm>. Acesso em: 01 nov. 2014.
} 


\section{Argumentos contra e a favor do extrativ- ismo de baixa tecnologia}

Esta seção se divide em tópicos analíticos. Para cada tópico colocamos as questões básicas, as suas implicações, algumas ambiguidades, além das visões que existem sobre o assunto, concluindo com a nossa própria avaliação. Alguns tópicos se sobrepõem parcialmente a outros, o que gera algumas repetições inevitáveis.

\subsection{As atividades extrativistas têm uma longa história na Amazônia}

Estudos arqueológicos e antropológicos, narrativas de mitos, etnografias contemporâneas e antigos relatos de missionários, governantes e viajantes permitem inferir que a extração de componentes da flora e da fauna (inclusive aquática) de áreas florestadas e conexas (rios, lagos, praias, igapós, cerrados, manguezais, etc.) tem sido o meio fundamental de subsistência para a maior parte dos seres humanos que viveram na Amazônia nos últimos milhares de anos. Isso não é surpresa, pois, como destacamos, durante a maior parte da história da espécie humana o extrativismo foi a maneira de produzir que prevaleceu para o conjunto da nossa espécie, em todos os biomas ocupados por ela. Em alguns lugares dos trópicos, o extrativismo se combinou de diversas maneiras com formas simples de agricultura. Nas florestas tropicais sul-americanas, esse modo de vida que combina extrativismo com agricultura (chamado de "policultura tropical") foi estudado a fundo por antropólogos e ecólogos humanos desde as décadas de 1930 e 1940 e foi considerado como uma bem-sucedida forma adaptativa de subsistência adotada por muitos povos (Steward, 1946-1959; Meggers, 1971).
No entanto, pesquisas de Anna Roosevelt revelaram que em pelo menos algumas porções do vale central do rio Amazonas (a região da Pedra Pintada, perto da cidade de Monte Alegre, Pará, e parte da ilha de Marajó, também no Pará) parecem ter sido ocupadas, por algum tempo, por civilizações agrícolas relativamente complexas. No entanto, não foram tão complexas e duráveis quanto as que floresceram nas montanhas e platôs dos Andes, da América Central e da América do Norte (atual território mexicano), que criaram sistemas agrícolas complexos de grande porte (Brito, 1990; Roosevelt, 1999a; 1999b).

É improvável, no entanto, que mesmo essas sociedades amazônicas complexas tenham aberto mão completamente das atividades extrativistas, mesmo nos seus momentos de maior prosperidade. Tudo indica que a maior parte das sociedades amazônicas passou por longos estágios de comunidade primitiva, em que a extração forneceu a maior parte dos meios de subsistência, por vezes em combinação com os produtos da agricultura itinerante, ou de queimada, distinta da agricultura praticada pelas citadas sociedades complexas. Essa combinação de atividades extrativas e policultoras faz parte até hoje das estratégias produtivas de grupos nativos da região e de migrantes mais recentes.

Portanto, o extrativismo tem uma longa história na Amazônia, contribuindo para sustentar os milhões de pessoas que viveram e ainda vivem lá, antes e depois da formação e do desaparecimento das sociedades complexas locais, antes e depois da chegada de europeus, herdeiros propagadores da revolução neolítica da agricultura e da pecuária do Velho Mundo. Por isso, o extrativismo contemporâneo não pode ser tratado depreciativamente como uma "moda" que tende ao fracasso comercial, nem romanticamente como uma solução origina- 
líssima de residentes que vivem numa "harmonia" singular com a natureza, e nem mesmo como uma "distorção colonialista" introduzida ou imposta pelos colonizadores europeus. É evidente que as atividades extrativistas da Amazônia mudaram depois da penetração europeia, mas quase todos os ciclos extrativos modernos e propriamente comerciais da Amazônia foram baseados nas famosas "drogas do sertão" - bens conhecidos e usados pelos locais antes da presença europeia, como o cacau, a castanha, os ovos e óleos de tartarugas, as penas de aves, os couros de jacarés e as carnes de inúmeros peixes e mamíferos aquáticos. Ou seja, ocorreu na Amazônia, após o ano de 1492, uma penetração mútua entre os conhecimentos locais sobre a natureza e o impulso comercial dos europeus, não muito diferente da que ocorreu em outros pontos do território brasileiro entre portugueses e franceses, de um lado, e indígenas, de outro, envolvendo o pau-brasil, nativo da Mata Atlântica.

\subsection{As florestas amazônicas foram em parte modificadas pela ação humana}

A Amazônia teve muitos milhões de habitantes, por milhares de anos. Houve algumas sociedades complexas, sedentárias, mais densamente povoadas, talvez mais estáveis, e um número maior de sociedades classificadas como "comunidades primitivas" - população pequena, nômades ou seminômades, e com estruturas sociais mais simples. Nas primeiras, muito provavelmente houve campos agrícolas permanentes e extensos e ocorreu o uso de muitos recursos naturais em larga escala - solos agrícolas, madeira e outros produtos vegetais, animais de caça e pesca, materiais de construção, etc. Nas segundas, várias dinâmicas sociais provocavam migrações sazonais, o nomadismo ou o seminomadismo, e a repartição das aldeias, todas igualmente consumidoras de recursos naturais, embora em escala menor (Denevan \& Padoch, 1988; Hemming, 2008).

Pelo que se sabe, todos os amazônidas nativos, desde milhares de anos antes do seu contato com europeus, controlavam o fogo, caçavam, pescavam e coletavam dezenas ou centenas de produtos vegetais; muitos praticavam agricultura itinerante. Tudo isso deu ampla oportunidade para que trechos das florestas e de outras formações vegetais fossem modificados pela ação humana, principalmente ao longo de rios, vias de migração terrestres ("causeways") e em torno das aldeias. Esses trechos de florestas tropicais não podem ser considerados, portanto, "virgens". Hecht \& Cockburn (1989) e Denevan (1992a; 1992b; 2011), entre outros, argumentam, com base em cuidadosas pesquisas de campo, que as florestas perto de aldeias e rios navegáveis resultam tanto de processos ecológicos "naturais", livres de interferências humanas intencionais, quanto da introdução deliberada de algumas espécies vegetais úteis e a eventual construção de terraços que permitiam cultivos permanentes em áreas de várzeas.

Existem várias hipóteses sobre a formação da chamada "terra preta de índios" (TPI) em diversos locais da Amazônia. Miller (2007), citando vários autores, considera a TPI uma evidência eloquente de uso agrícola continuado de solos, anterior à presença europeia. Ele as trata como uma prova a mais - par e par com obras mais explícitas, como aquedutos, terraços agrícolas, curvas de nível, estradas, pirâmides, palácios e grandes cidades de sociedades complexas de várias partes da América Latina - de que o continente americano como um todo nada tinha de "virgem" quando da chegada dos europeus. A hipótese mais provável da origem da 
TPI é de que tenham sido formadas de modo não intencional pelas práticas agrícolas continuadas de grupos nativos sedentários em tempos pré-colombianos.

Havia ainda formas de manejo da paisagem que combinavam o extrativismo com um esforço concentrado de produzir formações com plantas úteis. Anthony Anderson e Darrell A. Posey (1985) pesquisaram um dos tipos de manejo do Cerrado realizado por índios Kayapó na bacia do rio Xingu; ele provavelmente deu origem às TPIs locais. Os Kayapó faziam plantios intencionais, ou seja, criavam "ilhas" de vegetação útil ao longo de suas rotas migratórias, o que dava mais segurança aos seus deslocamentos.

Por tudo isso, é errado dizer que o extrativismo de baixa tecnologia, em tempos passados ou presentes, deixe as florestas tropicais num estado "virgem", com a sua biodiversidade intacta. Pelo contrário, é inevitável que o extrativismo introduza mudanças sistemáticas na floresta, principalmente quando se concentra em materiais reprodutivos de plantas e animais (sementes e ovos, por exemplo). O grau de mudança causada pelo extrativismo voltado para a subsistência ou para trocas locais é, no entanto, muito menor do que o de qualquer outra atividade produtiva (mesmo em modo extrativo) voltada para mercados. Mesmo que o extrativismo não cause desmatamento ou a eliminação radical dos ecossistemas em que é praticado, ele altera esses ecossistemas, especialmente quando combinado com a agricultura de queimada. Em suma, o extrativismo de baixa tecnologia faz parte do longo processo de modificação antrópica de pelos menos algumas partes das florestas tropicais da Amazônia, mas ele permite que essas florestas continuem a ter sistemas ecológicos complexos, alta produtividade biológica e rica biodiversidade e, mais relevante para o nosso texto, permite que elas continuem a gerar produtos extrativos.

\subsection{O extrativismo gerou produtos comercialmente bem-sucedidos}

Uma grande parcela da produção extrativista amazônica do passado e do presente não ultrapassou ou não ultrapassa os circuitos locais de subsistência e escambo. Depois da penetração europeia, no entanto, muitos produtos extrativistas encontraram o caminho de mercados comerciais relativamente amplos e prósperos, nacionais ou mesmo internacionais. Alguns alcançaram preços de razoáveis a bons por muitos anos ou décadas. O guaraná (Paullinia cupana Kunth), o cacau (Theobroma cacao L.), a castanha-do-pará (Bertholettia excelsa Kunth) e a borracha (Hevea brasiliensis), para citar exemplos mais conhecidos, conquistaram mercados duradouros e angariaram fortunas para intermediários e comerciantes locais e internacionais, embora não para os próprios extratores. Por isso, é errado criticar o extrativismo com base na alegação de que os bens coletados não conseguem alcançar o status de bens comerciais ou commodities.

Pelos mesmos motivos acima, é também incorreta a afirmação correlata de que o extrativismo é pela sua própria natureza fadado a existir apenas no nível de subsistência ou de troca local. É claro que não existe garantia de que um produto extrativo de baixa tecnologia vá alcançar e manter a condição de commodity. Aliás, essa mesma incerteza, em grau mais brando, ocorre também com bens extrativos de alta tecnologia (basta lembrar os ciclos de altas e baixas dos preços de diversos minérios e do petróleo) e até com commodities agropecuárias bem estabelecidas no mercado (flutuações nos preços de grãos, por exemplo). 
Homma et al. (2006) (ver também Homma, 2012) destacam a instabilidade comercial que afeta os bens extrativos, mesmo aqueles que alcançam sucesso no mercado, descrevendo a sua passagem por cinco etapas/processos: (i) cresce a produção do bem extraído em função da sua aceitação no mercado; (ii) o preço do bem tende a subir depois que o limite da capacidade de produção via extrativismo é atingido e o bem se torna escasso; (iii) escassez e carestia estimulam o manejo, ou a domesticação, ou o cultivo sistemático das plantas e dos animais antes extraídos/caçados; (iv) alternativa ou simultaneamente, ocorre a substituição do bem extrativo escasso e caro por outros bens extrativos concorrentes no mercado, oriundos ou não da mesma região; (v) escassez e carestia estimulam a concorrência ou a substituição dos bens extrativos por substâncias sintéticas.

Mais recentemente as indústrias de cosméticos e as bioindústrias nacional e internacional ganharam visibilidade com o desenvolvimento de produtos oriundos do uso alegadamente sustentável da biodiversidade da região amazônica. As bioindústrias trabalham com plantas nativas para produzir essências, vacinas, medicamentos e formulações para cosméticos a partir de produtos extrativos (Araújo, 2005; Fusco, 2010). Alguns exemplos são a compra e o uso de óleos de castanha (Bertholettia excelsa Kunth), andiroba (Carapa guianensis Aublet), murumuru (Astrocaryum murumuru) e copaíba [Copaifera langsdorfii (Desf.) Kuntze]. A produção e a comercialização ocorrem no âmbito de parcerias entre comunidades extrativistas e empresas do setor, que têm tido uma demanda crescente por bens ligados a produtos "naturais" e a práticas mais "sustentáveis" e socialmente responsáveis. Essa frente de aproveitamento de produtos do extrativismo abrange diversos setores e produtos, como óleos essenciais, plantas medicinais, fibras e resinas (Almeida \& Tourinho, 2011).

Um exemplo desse tipo de parceria ocorre desde 2000 entre a Natura (empresa privada brasileira) e a Cooperativa Mista de Produtores e Extrativistas do Rio Iratapuru-Comaru - COMARU (Amapá). A primeira venda de óleo bruto da castanha-do-Brasil pela cooperativa ocorreu em 2003. O óleo é vendido para a Cognis do Brasil, a sua maior cliente e responsável pelo refino do óleo; depois dessa etapa industrial o óleo é vendido para a Natura. As áreas de coleta da castanha são certificadas pelo Forest Stewardship Council (Tavares et al., 2010).

O esforço extrativista em torno da produção da castanha e derivados e a valorização desses produtos já engendraram iniciativas em torno do manejo intensivo da castanheira e mesmo de plantações sistemáticas de castanheiras. Na Floresta Nacional Saracá-Taquera (Pará), castanheiras plantadas em áreas degradadas pela mineração de bauxita demonstraram ótima adaptação e crescimento no contexto de plantios heterogêneos (Salomão et al., 2006). Em artigo recente, Homma (2012, p. 178) registra que está em "plena produção" uma grande plantação de castanheiras (300 mil indivíduos, ocupando 3.000 hectares), localizada na estrada que liga Manaus a Itacoatiara (Amazonas).

Mesmo um produto extrativo que passou por um ciclo de boom and bust, como a borracha da Amazônia brasileira, pode ser transformado e comercializado de forma a valorizar e melhor remunerar os extratores. A primeira e mais antiga forma comercial da borracha amazônica foi o "Cernambi Virgem Prensado" (CVP), também chamado de "borracha bruta", que continua a ser produzido. Para produzir o CVP, o látex é coletado, coagulado e prensado em blocos. Porém, desde 2006, foi desenvolvida no Acre uma nova alternativa de 
tratamento do látex, o "látex líquido" (LL), produzido especialmente para ser fornecido à "Fábrica de Preservativos Masculinos Xapuri - Preservativos Natex" (Ponte \& Thomaz Junior, 2012).

Uma terceira forma de apresentação da borracha nativa é a FDL ("Folha Defumada Líquida"), a partir de uma tecnologia desenvolvida por pesquisadores da Universidade de Brasília (UnB). O resultado é um produto de alta qualidade, usado principalmente pela indústria de calçados. $\mathrm{O}$ material é usado em uma linha de calçados esportivos da marca alemã eco-friendly "Veja Fair Trade", conhecida pelo nome "Vert". Os calçados são produzidos no Rio Grande do Sul e exportados para a Alemanha. A experiência da Vert começou com os seringueiros da Reserva Extrativista Chico Mendes, em Assis Brasil, Acre, e hoje envolve três associações de seringueiros. A compra da borracha é feita por um "preço justo". Em uma das associações, no município de Feijó, cerca de 30 famílias extrativistas produzem seis toneladas de borracha para a fabricação dos calçados Vert (Ponte \& Thomaz Junior, 2012).

De Carlo \& Drummond (2004) estudaram um caso recente e emblemático de absorção de um tradicional produto extrativo das florestas tropicais, nativo das Américas do Sul e Central, o urucum (Bixa orellana), por um mercado "moderno" de cosméticos feitos com base em matérias-primas naturais. O urucum era usado desde tempos pré-colombianos, como produto extraído, por nativos das Américas como tintura para colorir tecidos e pintar o corpo, como repelente de insetos e como complemento alimentar. Mas, no século XX a planta já fora domesticada e plantada no Brasil e em vários países fora das Américas, deslocando a produção extrativa brasileira. Intensivamente usado durante décadas como tintura para têxteis, como colorante de queijos, manteigas, iogurtes, massas, carnes, etc., e como componente de cosméticos, na década de 1940 o urucum acabou substituído por colorantes sintéticos. Anos mais tarde, porém, esses sintéticos se revelaram cancerígenos.

Com isso, as plantações de urucum passaram por uma revivescência em várias partes do mundo. Na década de 1990, uma empresa multinacional de cosméticos "naturais", Aveda, se interessou por financiar a produção de urucum pelos Yawanawá, tribo indígena residente no Acre. A parceria funcionou mas é de se notar que os indígenas não produziram o urucum extraído: fizeram plantios do urucuzeiro, para o que necessitaram do apoio técnico de extensionistas da Embrapa. Além disso, tiveram que adotar e aprender a usar um maquinário para fazer o processamento primário do urucum (permitindo o seu aproveitamento industrial nas fábricas da Aveda) (ver Sampaio et al., 2000).

Topik et al. (2006) editaram uma coletânea que ilustra a riqueza da produção de commodities na América Latina, em escala continental. Cada capítulo focaliza uma commodity produzida e exportada de diferentes regiões da América Latina em tempos coloniais e pós-coloniais. Os autores estudam as cadeias produtivas geradas por uma amostra de 12 materiais extrativos, minerais e agrícolas, entre os quais prata, anil, cochonilha, tabaco, café, açúcar, banana, guano, nitratos, borracha e cocaína. Impressionam a variedade dos bens, os volumes físicos de produção e exportação, os valores financeiros, os ciclos de ascensão, estagnação e esgotamento/crise - e principalmente as duradouras marcas que toda essa movimentação produtiva deixou nas sociedades nacionais e regionais, muitas das quais como que se "viciaram" na exportação de bens primários, extraídos ou não. 
A variedade de commodities e bens primários produzidos contemporaneamente no Brasil ainda é grande e continua a crescer. O Instituto Brasileiro de Geografia e Estatística - IBGE publica anualmente um estudo intitulado Produção da Extração Vegetal e da Silvicultura - PEVS. O objetivo é informar a quantidade e o valor das produções do extrativismo e da silvicultura em todo o país. Os dados são coletados a partir de consulta a entidades públicas e privadas, produtores, técnicos e órgãos ligados direta ou indiretamente aos setores da produção, comercialização, industrialização e fiscalização de produtos vegetais nativos, bem como daqueles produtos originados de maciços florestais plantados (IBGE, 2014, p. 10). Essa base de dados ajuda na construção e no entendimento dos cenários de produção e de viabilidade comercial de bens oriundos do extrativismo. A pesquisa considera como produtos extrativistas aqueles que vêm da exploração dos diversos tipos de flora nativa. Divide-os em oito grupos: (i) borrachas; (ii) ceras; (iii) fibras; (iv) tanantes; (v) oleaginosos; (vi) alimentícios; (vii) aromáticos, medicinais, tóxicos e corantes; e (viii) madeiras (IBGE, 2014).

Os dados recentes do PEVS indicam que um número crescente de produtos e espécies vem sendo coletado e comercializado. Por causa disso, o IBGE busca ampliar a lista de produtos extrativistas não madeireiros que constam nos estudos da PEVS. Em 2013 e 2014, o órgão consultou de forma mais sistemática atores governamentais que fomentam o extrativismo, como a Companhia Nacional de Abastecimento - CONAB (Ministério da Agricultura, Pecuária e Abastecimento), o Departamento de Extrativismo - DEX - e o Serviço Florestal Brasileiro
(SFB) (ambos do Ministério do Meio Ambiente), e o Departamento de Geração de Renda e Agregação de Valor - DGRAV (Ministério do Desenvolvimento Agrário - MDA). Trata-se de uma resposta a uma demanda antiga desses órgãos ao IBGE, atendida apenas agora, provavelmente devido à expansão do mercado para produtos oriundos da biodiversidade (ver Lins, 2013).

No entanto, para que novos produtos sejam inseridos na pesquisa e no mercado, é necessário que eles sejam classificados de acordo com a "Nomenclatura Comum do Mercosul" - NCM". ${ }^{6}$ Para constar na NCM, um produto precisa passar pela Comissão Nacional de Classificação - CONCLA, a responsável pelo monitoramento, definição das normas de utilização e padronização das classificações nacionais de mercadorias. A comissão, criada em 1994, é formada por 17 ministérios e pelo IBGE. A última reunião que tratou da classificação de novos produtos extrativos ocorreu em $2010 .^{7}$ Isso mostra que existe uma considerável "inércia" na classificação oficial e na geração de dados sobre produtos extrativos.

\subsection{O extrativismo dá origem a ou perpetua economias de mera subsistência que não superam baixos níveis de produtividade e de bem-estar}

Os habitantes das regiões rurais da Amazônia - sejam ou não extratores - estão entre os brasileiros mais pobres. A estrutura social atual da região, fortemente estratificada e excludente em termos de distribuição de renda, de acesso à terra e a outros recursos de subsistência e de serviços públicos

\footnotetext{
6 Adotada no Brasil e nos países do Mercosul a partir de 1995. Disponível em: <http://www.desenvolvimento.gov.br/sitio/interna/interna. php?area=5\&menu=1090>. Acesso em: 10 mar. 2015.

7 Informação disponível em: <http://www.desenvolvimento.gov.br/sitio/interna/interna.php?area=5\&menu=1090>. Acesso em: 10 mar. 2015.
} 
básicos, deve muito aos explosivos ciclos de prosperidade e declínio típicos do extrativismo. A falta de agregação local de valor a muitos produtos regionais amazônicos - tema tratado acima - também contribui para a pobreza da população regional.

É certo afirmar, como faz Paulo Alvim (1990), que os extratores amazônicos são pobres e continuarão a ser pobres enquanto estiverem presos a ciclos extrativos efêmeros e/ou à agricultura de subsistência, mas isso não deve obscurecer outro fato: os coletores amazônicos não são os brasileiros mais pobres, nem os que têm piores perspectivas. O "núcleo duro" regional da pobreza no Brasil é o chamado Semiárido, que cobre a maior parte do interior dos estados da Região Nordeste. Ele corresponde a cerca de $11 \%$ do território nacional e inclui partes de nove estados brasileiros (Rocha, 2003). Que essa área contém o "núcleo duro" da pobreza brasileira é demonstrado por dados censitários, por dados das PNADs, pelos escores de IDH e até pela distribuição dos beneficiados pelos atuais programas de transferência de renda.

Embora a Caatinga, bioma predominante na quase totalidade do Semiárido, se preste a atividades extrativistas, ela não pode ser comparada em termos de riqueza vegetal e animal aos biomas de floresta tropical úmida. Em outras palavras, a substituição do extrativismo por atividades produtivas voltadas para o mercado e que eliminem as florestas não garante melhores condições de vida para os amazônidas que hoje são exclusiva ou principalmente extratores. É cabível afirmar que os produtos extrativos florestais funcionam para eles como uma "dispensa" natural que pode evitar que eles passem por privações absolutas. Os pobres rurais residentes em áreas de floresta tropical úmida desmatadas - ou da Caatinga - não contam com essa "dispensa", como é evidenciado por duradouros bolsões de pobreza existentes em diversos trechos desmatados da Mata Atlântica - os vales dos rios Paraíba do Sul e Jequitinhonha, por exemplo.

\subsection{Plantas e animais coletados tendem a} ser substituidos (i) por plantas e animais domesticados elou (ii) por outros produtos vegetais e animais coletados elou (iii) por produtos sintéticos

Ao longo da história da humanidade, muitos produtos extrativos, e não apenas os das florestas tropicais, foram deslocados de suas posições em mercados locais, nacionais e internacionais em virtude de sua domesticação. Isso pode ocorrer na própria região original de coleta, em outras partes de cada país ou em outras partes do mundo. Apesar de muitas vezes exasperar os extratores, os estudiosos e gestores que buscam apoiar o extrativismo, trata-se de um fenômeno recorrente ao qual estão sujeitos os bens de origem extrativa.

A própria domesticação das plantas que hoje são as principais bases alimentares da humanidade substituiu, há milhares de anos, a coleta das suas parentes selvagens nos seus locais de origem natural, embora os efeitos disso sobre os coletores da época não tenham sido os mesmos que os efeitos equivalentes de hoje. A importância da coleta continuada de parentes "selvagens" de trigo, milho e arroz, três dos mais importantes alimentos do mundo atual, é irrisória em face das maciças colheitas retiradas dos extensos plantios existentes há milênios.

No caso do Brasil de ontem e hoje, as preocupações com a "pirataria" que ameaçaria as riquezas naturais que ocorrem no nosso território convivem um tanto contraditoriamente com os amplos cultivos de plantas e enormes plantéis de animais oriundos de outras partes do continente americano e principalmente de outros continentes. 
É verdade que vários produtos nativos coletados no território brasileiro foram total ou parcialmente deslocados por atos de domesticação ocorridos no Brasil ou fora dele - a seringueira, o cajueiro, o guaraná, o cacaueiro, o urucuzeiro, etc. Mas, não se pode esquecer que praticamente toda a nossa agricultura, seja familiar, seja comercial de grande escala, e mesmo a agricultura de subsistência, adota plantas e animais introduzidos: arroz, trigo, aveia, sorgo, milho, soja, cana-de-açúcar, laranja e cítricos em geral, café etc., além de bois, porcos, cavalos, cabras, ovelhas, galinhas, perus, etc.

As bem-sucedidas plantações de seringueiras no sudeste asiático, estabelecidas a partir dos anos 1870, são o exemplo clássico e mais bem conhecido pelos brasileiros de plantas "pirateadas" e depois domesticadas que retiraram as suas "irmãs" selvagens do mercado ou as restringiram radicalmente (Dean, 1987). Na própria Amazônia brasileira houve uma tentativa ambiciosa - e fracassada - de produzir borracha a partir de plantações de seringueiras, levada a cabo por Henry Ford, norte-americano, industrial e ideólogo da industrialização (Dean, 1987; Costa, 1993; Jackson, 2008; Grandin, 2009).

O mesmo fenômeno de deslocamento de produtos naturais coletados foi e continua a ser causado não apenas por domesticações recentes, mas por sucessivas descobertas ou invenções de produtos sintéticos substitutivos de matérias-primas naturais, via de regra, realizadas por cientistas e laboratórios de países desenvolvidos. A borracha amazônica, a mesma que era extraída em seus locais de ocorrência natural, sofreu um segundo impacto sério, mais recente, além da mencionada domesticação da seringueira e do seu plantio maciço no sudeste asiático. Esse segundo impacto foi a in- venção da borracha sintética, ocorrida em diversos episódios isolados entre si, por pesquisas feitas por cientistas de países desenvolvidos, começando em fins do século XIX. As guerras mundiais do século XX aceleraram a adoção da borracha sintética, que foi substituindo a borracha natural em muitas aplicações. Há vários tipos de borracha sintética, derivados do petróleo. Algumas ainda têm um conteúdo parcial de borracha natural, mas outras são puramente sintéticas. É desnecessário dizer que a disponibilidade da borracha sintética fez com que o mercado para a borracha nativa extraída na Amazônia sofresse esse segundo golpe, que ocorreu não muito depois do primeiro golpe, causado pelo início da produção das plantações asiáticas da seringueira, em torno de 1910.

O Brasil atualmente importa grande parte da borracha que consome. Conforme os últimos dados publicados da PEVS, a produção brasileira de borracha extraída na forma de látex coagulado em 2012 foi de 2.143 toneladas; em 2013, foi de 1.760 toneladas. Essa produção está concentrada nos estados de Rondônia, Acre, Amazonas, Pará e Amapá. Quanto ao látex líquido de borracha natural extrativa, a produção foi de 198 toneladas, oriunda dos estados de Acre e Amapá (IBGE, 2014). Essas cifras são irrisórias no quadro nacional do consumo e de produção de borracha natural. Mesmo que essa produção extrativa oriunda da Amazônia esteja gerando bons rendimentos para os seringueiros (o que é duvidoso), o volume de produção está longe de atender às necessidades nacionais.

O quadro da borracha extraída no Brasil fica ainda mais precário quando se leva em conta a produção brasileira de borracha a partir de plantios de seringueiras. Segundo dados do Polo de Excelência em Florestas, ${ }^{8}$ o Brasil tinha em 2012 uma área

8 Ver Polo de Excelência em Florestas, <http://www.ciflorestas.com.br/dado.php?id=69>, acesso em: 03 abr. 2015. 
plantada com seringueiras de 168.000 hectares, mas ainda dependia de importações para suprir sua demanda. Em 2012, o Brasil produziu 172.000 toneladas, cerca de $1,51 \%$ da produção mundial (cerca de 11 milhões de toneladas). No entanto, o Brasil consumiu no mesmo ano 343.000 toneladas, sendo obrigado a importar 171 mil toneladas. Surpreende muitos extratores e simpatizantes deles saber que já há algum tempo a produção de borracha nativa no Brasil depende fortemente de seringais plantados fora da Amazônia (São Paulo, Mato Grosso do Sul, Bahia e Espírito Santo). Eles foram responsáveis em 2012 por $92,63 \%$ da produção brasileira. Seis estados amazônicos produzem os 7,37\% restantes a partir de seringais nativos (IAC, 2015).

O cacau (Theobroma cacao L.) tem uma trajetória ainda mais "tortuosa" que a da borracha no que toca à sua domesticação e à sua inserção nos mercados globais. O cacaueiro é nativo da Amazônia. Ele foi domesticado séculos antes da chegada de europeus ao continente americano, provavelmente nas florestas tropicais úmidas da atual Venezuela, e transferido, já como planta domesticada, para várias partes da América Central e para o território atual do México. No entanto, em outras partes da Amazônia, a árvore continuou a ser explorada de forma extrativa, integrando o grupo das famosas "drogas do sertão" amazônicas (Young, 2007).

A sua exploração como planta cultivada se espalhou pelo mundo e pelo próprio Brasil. Até fins da década de 1980, o Brasil ocupou o segundo lugar em escala mundial como produtor de cacau plantado (principalmente na Bahia), porém nos anos 1990 a produção caiu substancialmente com o ataque de uma doença fúngica (popularmente chamada de "vassoura-de-bruxa") às plantações da Bahia. Hoje, o Brasil ocupa a sexta posição, tendo produzido apenas 200.000 toneladas na safra
2010/2011. A Costa do Marfim liderava o ranking mundial nesse mesmo ano, com uma produção de 1,51 milhão de toneladas (Müller, 2012).

Existem muitos outros exemplos de domesticação de bens vegetais nativos amazônicos cuja produção foi ou ainda é extrativa, ao menos parcialmente. O guaraná (Paullinia cupana H.B.K.) foi objeto de coleta de várias populações nativas da Amazônia. Com a domesticação ocorrida na década de 1970, ele foi plantado em outras partes do Brasil. Atualmente, os principais estados produtores de guaraná plantado são Bahia (61\% da produção), Amazonas (23\%), Mato Grosso, Acre e Pará. A produção mundial do guaraná está concentrada quase que totalmente no Brasil, sendo que Peru e Venezuela são pequenos produtores. A safra de 2012 foi de 4.028 toneladas, cultivadas numa área de 13.898 hectares (Tfouni et al., 2007; Homma, 2011; 2012; CONAB, 2013).

O pau-brasil (Caesalpinia echinata), nativo da Mata Atlântica, cuja importância comercial foi tão grande a ponto de dar o nome à colônia-país, foi secularmente explorado como bem extrativo e exportado continuamente até depois de meados do século XIX (Castro, 2002). A sua madeira ainda tinha bom valor comercial em meados do século XIX, mas a descoberta de anilinas sintéticas por químicos franceses e alemães, no início do mesmo século, e a sua comercialização ampliada, a partir de 1850, substituíram o uso do pau-brasil como fonte de tintura. Hoje, a madeira do pau-brasil, retirada quase exclusivamente de plantios, serve principalmente para fabricar arcos de violino e violoncelo de alta qualidade e diversos tipos de artesanato (Bueno et al., 2002; Aguiar \& Pinho, 2007).

O óleo de pau-rosa (Aniba rosaeodora Ducke) é extraído da madeira de uma árvore que ocorre naturalmente no Brasil, Equador, Colômbia, Guiana, 
Guiana Francesa, Peru, Suriname e Venezuela. ${ }^{9}$ No Brasil, ela ocorre principalmente nos estados do Pará, Amapá e Amazonas. Os primeiros registros de sua exploração datam de 1883, na Guiana Francesa. O óleo essencial era destilado em Paris. No Brasil a árvore foi descoberta comercialmente em 1925, em Juriti Velho, Pará, e a extração começou em 1926 (Homma, 2005a). O seu óleo essencial é utilizado principalmente como substância fixadora de perfumes. Em 1951, o Brasil exportou 444 toneladas de óleo de pau-rosa; em 2005, a quantidade exportada foi de apenas 39 toneladas (Homma, 2005a; 2005b), embora haja suspeitas de que ocorra um volume muito maior de exportações ilegais. Um dos motivos para a queda vertical da produção registrada é o fato de que a árvore precisa ser derrubada para a retirada do óleo. Significativamente, o pau-rosa consta entre as espécies da flora ameaçadas de extinção no Brasil ${ }^{10}$ e aparece na lista vermelha da UICN $^{11}$, na condição de ameaçada. Este é mais um caso em que o sucesso comercial de um bem extraído conflita com a sustentabilidade de sua extração.

O bacuri (Platonia insignis Mart.), árvore frutífera nativa da Amazônia, tem ganho muito espaço nos mercados regionais. Toda a sua oferta é de origem extrativa. Essa situação é propícia, de acordo com o mencionado esquema analítico de Homma, para que ocorram esforços no sentido de domesticação da planta. Conforme o próprio Homma (2011), o nordeste paraense já poderia ter se transformado em um grande centro produtor de bacuri, com área plantada equivalente à do cupuaçu [Theobroma grandiflorum (Spreng) Schum], outra árvore frutífera amazônica que está em fase de transição da coleta para a produção cultivada, contando com mais de 25 mil hectares plantados na Amazônia - o Pará é o principal produtor, seguido do Amazonas, Rondônia e Acre.

Cosméticos, fármacos e a fruticultura continuam a ser nichos de mercado para produtos do extrativismo amazônico. Exemplos deles são açaí (Euterpe oleracea Mart.), taperebá (Spondias mombin L.), murici [Byrsonima crassifolia (L) H.B.K.], tucumã (Astrocarium vulgare Mart.), pupunha (Bactris gasipaes H.B.K.), andiroba ( $\mathrm{Ca}$ rapa guianensis Aublet), murumuru (Astrocaryum murumuru), copaíba [Copaifera langsdorfii (Desf.) Kuntze] e uxi [(Endopleura uchi (Huber) Cuatrecasas] (Homma, 2011; 2012).

Estamos neste tópico dando vários exemplos de como qualquer produto extrativo de origem vegetal ou animal corre o risco de ser domesticado, alterado, produzido em escala industrial e/ou replicado em laboratório e substituído por sintéticos. No entanto, é preciso destacar que esse risco afeta também produtos agrícolas e pecuários estabelecidos, produzidos com tecnologias modernas e para mercados amplos. Plant breeding e animal breeding (melhoramento vegetal e animal), a moderna ciência dos materiais, a engenharia genética e a biotecnologia são setores sólidos e dedicados sistematicamente a facilitar a produção de bens naturais ou a substituí-los, seja por seres vivos modificados ou por materiais sintéticos. Esse tipo de ameaça atinge, pois, tanto produtos vegetais e animais extraídos quanto os cultivados, incluindo muitos produtos do moderno agronegócio.

\footnotetext{
9 Sampaio, P. T. B.; Ferraz, I. D. K.; Camargo, J. L. C. Manual de Sementes da Amazônia - Pau-rosa (Aniba rosaeodora Ducke). Instituto Nacional de Pesquisas da Amazônia (INPA). 2003 (3). Disponível em: <https://www.inpa.gov.br/sementes/manuais/fasciculo3_aniba.pdf>. Acesso em: 14 set. 2014.

10 Disponível em: <http://www.mma.gov.br/estruturas/ascom_boletins/_arquivos/83_19092008034949.pdf>. Acesso em: 10 mar. 2015.

11 Disponível em: <http://www.iucnredlist.org/details/33958/0> $>$. Acesso em: 10 mar. 2015.
} 
Os tempos modernos e contemporâneos são marcados por um ritmo veloz de turnover no uso de recursos naturais, especialmente no campo da energia e dos combustíveis. As florestas europeias, depois de milenarmente devastadas para usos agrícolas e pecuários, foram deslocadas como fontes de madeira para fins energéticos pelo uso do carvão mineral, que foi o combustível por excelência da revolução industrial. Isso ocorreu há cerca de 250 anos. Há 100 anos, o petróleo ainda era uma novidade que muitos consideravam sem futuro. Ele acabou substituindo rapidamente o carvão em muitas aplicações e abriu toda uma nova era de usos de energia em máquinas de novos tipos, inclusive o onipresente motor de combustão interna.

A hidroeletricidade foi outra novidade - tem mais ou menos a mesma idade do petróleo - no campo do suprimento de energia. Em numerosos casos substituiu com vantagens as fontes fósseis. Poucas grandes usinas hidrelétricas ainda em funcionamento no mundo têm mais de 80 anos de idade. No início da década de 1950, a energia nuclear ainda não se estabelecera como alternativa viável para suprimento de energia, mas isso ocorreu aceleradamente em um número significativo de países, alguns dos quais têm grande parte do seu suprimento energético oriundo da fissão nuclear. Nessa rápida sucessão de formas energéticas, diferentes recursos naturais - madeira, carvão mineral, petróleo, água e átomos - concorreram entre si e/ ou se somaram uns aos outros e/ou se substituíram parcialmente para gerar a energia exigida pelas sociedades humanas.

$\mathrm{Na}$ agricultura e pecuária têm ocorrido mudanças equivalentes, na tecnologia e nos cultivos. Os arados, milenarmente puxados por pessoas, cavalos ou bois até cerca de 100 anos atrás, são hoje movidos por veículos com motores de combustão interna. Instrumentos milenares da agricultura (enxada, pá, machado, facão, foice, serra, rodas d'água, etc.) foram substituídos por tratores, colheitadeiras, escavadeiras, bombas d'água, motosserras, pivôs, etc. Fertilizantes orgânicos foram deslocados por sucessivas gerações de sintéticos - tanto fertilizantes quanto herbicidas, fungicidas, inseticidas, etc. As sementes de trigo e milho plantadas hoje não são mais as sementes "melhoradas" da chamada "revolução verde" de algumas poucas décadas atrás, com as quais a moderna agricultura comercial inundou o mundo; essas sementes "melhoradas", por sua vez, não eram as que tinham alimentado a Europa e parte do continente americano por muitos séculos antes das ditas sementes melhoradas; por sua vez, essa geração de sementes era diferente das sementes do trigo e milho originalmente domesticados e/ou coletados no Levante e nos altiplanos mexicanos. Sementes e mudas melhoradas de todas as espécies cultivadas se tornaram componentes rotineiros em todos os ramos importantes da agricultura comercial. Os produtores que ignoram ou não têm acesso a essas novidades ficam em posição difícil nos seus respectivos mercados. O mesmo vale para os nossos principais animais domesticados, sujeitos a mudanças intencionais que invariavelmente buscam o aumento de sua produtividade - crescimento mais rápido, tamanho maior, maior rendimento leiteiro e de postura de ovos, períodos menores de gestação, etc.

Um ritmo ainda mais acelerado de turnover ocorre no campo dos materiais sintéticos. Há 100 anos os plásticos mal existiam fora de laboratórios e há 60 anos eles ainda engatinhavam na direção de usos mais ampliados. No entanto, hoje eles substituem amplamente materiais naturais, como madeiras, fibras, papéis, resinas e minerais diversos em inúmeras aplicações. Outro exemplo notável é 
o dos cabos de fibra ótica (novidade recente que já está quase obsoleta em algumas aplicações), cujo uso reduz drasticamente a necessidade de cabos de cobre para fins de telecomunicações. Adicionalmente, os volumes consumidos de matérias-primas naturais - coletadas ou cultivadas - ainda não substituídas têm sido sistematicamente reduzidos com base em tecnologias mais eficientes de produção e uso. Programas eficazes de reciclagem e reaproveitamento têm sido capazes de estabilizar ou diminuir a demanda por novas quantidades de matérias-primas naturais.

Assim, as ameaças que emergem da domesticação e/ou da sintetização são reais, múltiplas e se sucedem cada vez agilmente. Mas, elas não são um motivo suficiente para argumentar contra a viabilidade do extrativismo de baixa tecnologia, pois afetam indistintamente materiais naturais renováveis, bens agropecuários "modernos" e até recursos naturais não renováveis (minérios) produzidos de forma intensiva de capital.

\subsection{Os produtos extrativos têm preços de mercado instáveis}

Nas décadas recentes, continuou a ocorrer uma tendência antiga de declínio dos preços reais das matérias-primas e dos produtos primários em geral, extraídos ou cultivados, incluindo produtos agropecuários e minérios. Essa tendência e as suas implicações para a formação do mundo moderno, e especialmente das regiões, países e grupos sociais pobres, foram difundidas classicamente por Wallerstein $(1974 ; 1980 ; 1989)$ como componente visceral da formação do world system ("sistema mundo"). No entanto, elas mereceram um registro pioneiro feito por Raúl Prebisch, em 1950. Ele constatou numa tendência secular de "deterioração dos termos de troca", que fazia com que produtos primários perdessem valor de troca em relação aos produtos industrializados (Prebisch, 1950). Para constatar isso, ele usou uma abrangente base de dados sobre o comércio internacional mundial, cobrindo desde o fim do século XIX até o início da II Guerra Mundial. Em 1991, foi publicado um estudo desenhado especificamente para conferir se a teoria de Prebisch continuava a valer para além de 1950 (Diakosawas \& Scandizzo, 1991). Usando dados similares, os autores confirmaram a continuidade da tendência constatada por Prebisch para quase 40 anos depois do fim da II Guerra Mundial.

A análise dos índices de preços das commodities agrícolas e minerais (com exclusão do petróleo), divulgados pelo Fundo Monetário Internacional - FMI - nos últimos 20 anos, aproximadamente, mostra que entre 1991 e 2003 esses preços apresentaram suaves flutuações; de 2003 até julho de 2008 tiveram um forte aumento, que alimentou um boom de produção primária em muitos países, inclusive o Brasil; no entanto, em fins de 2008 houve forte queda e os preços voltaram aos patamares de 2006. A partir de março de 2009, houve uma recuperação; os preços cresceram até abril de 2011, mas sem atingir os níveis registrados entre 2003 e 2008 (Serigati, 2012). Mais recentemente, liderados pelo preço do petróleo (que atingiu as menores cotações em quase 50 anos), os preços das grandes commodities têm estado persistentemente baixos, a ponto de fazer com que os governantes de países que os exportam façam seguidas exortações para o "retorno da normalidade". No entanto, a "normalidade" secular é a tendência ao declínio dos preços, salpicada de recuperações parciais e temporárias.

Apesar da disparada nos preços de alguns desses bens, ocorrida entre 2003 e 2008, e das previsões por vezes catastrofistas de ambientalistas 
e outros sobre a escassez/o esgotamento iminente desses bens, continua a prevalecer a mencionada tendência de queda de preços. Continuam a crescer também as diferenças entre esses preços e os de produtos secundários, terciários ou intensivos em informação, outra confirmação da visão de Prebisch de "deterioração dos termos de troca". Nas últimas décadas, portanto, caíram os preços de quase todas as principais matérias-primas - incluindo as que são produzidas de forma intensiva de capital, como ferro, alumínio, carvão, petróleo e gás natural; o mesmo aconteceu com os principais grãos e com várias outras commodities agrícolas. Isso evidentemente afeta os extratores de alta e baixa tecnologia de todas as partes do mundo.

Anderson et al. (1994) questionam as afirmações de que o extrativismo sofre de uma crônica inviabilidade econômica, uma vez que em geral não são levadas em conta mudanças sociais que poderiam melhorar a eficiência das economias baseadas em produtos florestais não madeireiros. Isso cria desvantagens para economias nacionais, regionais ou comunitárias excessivamente focalizadas nesses tipos de produtos. Esse questionamento tem razão de ser, mas ele não nega que o extrativismo vegetal apresenta uma tendência à ineficiência, nem que a superação dessa ineficiência enfrenta obstáculos sérios, o que se exacerba quando ocorre dependência excessiva em relação a ela (ver Ferreira, 1999; Damasceno, 2009; Cerqueira et al., 2011; CIFlorestas, 2013).

Como os produtos extrativos de baixa tecnologia são, por definição, primários, entendemos que a instabilidade e/ou a tendência à queda dos seus preços representam uma desvantagem econômica para eles e para os seus produtores. No entanto, geralmente a atenção dos observadores, produtores e cidadãos recai apenas sobre casos de falência ge- neralizada de economias extrativistas baseadas em um ou dois produtos. Na verdade, essa tendência de preços declinantes afeta negativamente ou ameaça (mesmo que não de forma ostensiva) todos os bens primários, de baixa ou alta tecnologia, e funciona como um calcanhar de Aquiles das economias regionais e nacionais excessivamente dependentes da produção de commodities.

Como tem uma economia historicamente extrativa, a Amazônia brasileira tem sofrido sistematicamente com a instabilidade dos preços de seus produtos primários, além dos problemas gerados pelas mencionadas domesticações e substituições por sintéticos. Essas quedas contribuíram para desorganizar estruturas produtivas, dispersar a população, prejudicar o bem-estar humano e tornar mais escassos os estoques de bens naturais. Embora seja certo dizer que as crises econômicas raramente se restringem aos setores de produção primária, é inquestionável a maior flexibilidade dos setores agrícola, pecuário, industrial e de serviços para contornar e sobreviver a essas crises. Depender do extrativismo num contexto de estagnação ou queda geral de preços de bens primários não é, de fato, posição confortável para indivíduos, empresas, grupos sociais, regiões, países ou grupos de países.

\subsection{Os produtos extrativos são intensivos em "capital natural" e por isso os seus preços são os mais baixos numa economia diversificada em que as cadeias produtivas são longas e agregam capital, tecnologia e trabalho a esses produtos}

Por definição, os produtos extrativos de baixa tecnologia são colocados no mercado a partir da coleta direta de estoques naturais, com intermediação de pouco capital e de uma mão de obra pouco quali- 
ficada, equipada com uma tecnologia rudimentar. A maior parte do valor desses produtos está embutida, portanto, nas suas características naturais (propriedades nutritivas, estéticas ou medicinais, teores de minério, aplicabilidade industrial, facilidade de acesso, potencial energético, etc.), características essas que não dependem do trabalho, do capital ou do engenho humanos. A essas características pouco ou nenhum valor é agregado localmente em termos de mão de obra, capital, tecnologia, transporte, design, marketing, etc. (Bunker, 1984; 1985).

Essa agregação ocorre em outras regiões, vizinhas ou distantes, e é feita por atores sociais que não são extrativistas - operários, gerentes, empresários, trabalhadores dos serviços, etc. Esses atores embolsam - legitimamente, aliás - a remuneração ligada às diversas etapas de agregação de valor. Assim, as economias extrativistas são "simples", "isoladas": praticamente não estabelecem backward linkages (conexões produtivas para trás) e estabelecem poucas forward linkages (conexões produtivas para frente) com setores industriais, comerciais e de serviços (Hirschman, 1958).

Falta às economias extrativistas a diversificação de atividades característica das economias ricas ou desenvolvidas. Em virtude de sua própria composição simplificada, as economias extrativistas são muito suscetíveis a colapsos quando o principal componente do valor - as características naturais, que estão fora do controle humano - dos seus bens se deteriora ou sofre a competição de um substituto natural, agropecuário ou sintético. A atividade pesqueira, em que o tamanho médio dos peixes capturados diminui ao longo dos anos, é um exemplo clássico; minérios de teor declinante oriundos de uma mesma mina são outro exemplo; madeiras de mais baixa qualidade que vêm de uma operação madeireira também ilustram a importân- cia central das características naturais dos bens extrativos.

Além disso, os maiores e mais rápidos retornos de capitais investidos ocorrem nas indústrias de alta tecnologia, nos serviços mais sofisticados, nos ramos intensivos de informação e na criação de novos produtos. Os setores extrativos são lentos e pesados e competem muito fracamente com eles por capital, tecnologia e trabalho.

Os "capitais naturais" (ou ativos naturais), em casos de extrema raridade ou de valor estratégico, ocasionalmente alcançam alta valorização no mercado, mesmo sem agregação de valor. No entanto, em geral uma economia diversificada remunera menos os produtos "crus" da natureza e muito mais os produtos modificados pelo trabalho qualificado, por ferramentas e máquinas, pela transformação e pelo acabamento industriais, pelo desenvolvimento do próprio produto, pelo financiamento, pelo gerenciamento, pelo marketing e pela comercialização. A não ser que haja arranjos compensatórios, os componentes naturais de um produto são quase sempre os que recebem a mais baixa remuneração, mesmo que façam parte de bens tecnologicamente sofisticados.

Bunker (1985) coloca a questão da seguinte forma: as regiões/economias extrativas "bombeiam para fora" valores naturais que são economicamente transformados, expandidos e trocados nas economias "metropolitanas". Num mundo marcado por agudas diferenças econômicas de país a país e mesmo no interior de alguns países industrializados (como o Brasil), os bens produzidos por mão de obra mais altamente qualificada, com processos produtivos modernos e com intensidade de capital derrubam os rendimentos e a lucratividade dos produtores de bens primários, principalmente dos produtos extrativos de baixa tecnologia. Isso 
impede uma integração equilibrada das economias extrativistas nas redes regionais, nacionais e internacionais de produção e trocas. Embora não concordemos com a proposição de Bunker de que todas as regiões extrativas estão fadadas a viver uma espiral de decadência e de colapso econômico e ecológico, a verdade é que atualmente as perspectivas desenvolvimentistas dessas regiões são sombrias.

\subsection{As florestas tropicais úmidas contêm mais formas de vida úteis aos humanos do que as que já foram descobertas nelas}

Vejamos uma outra ordem de tópicos, mais estritamente ecológicos (no sentido de que envolvem questões da ciência da ecologia). Mesmo as estimativas mais conservadoras sobre o número de espécies de fauna, flora e microrganismos existentes nas florestas tropicais do mundo apontam para duas fortes probabilidades: (i) elas abrigam elevados números (na casa de milhões ou talvez até dezenas de milhões) de formas de vida, a maior parte ainda desconhecida da ciência e mesmo dos chamados "saberes locais"; e (ii) um número significativo dessas formas de vida desconhecidas pode ser útil para a humanidade, de maneiras ainda desconhecidas. Esse segundo ponto já envolve mais do que a ecologia, pois valoriza a biodiversidade tropical na medida da sua utilidade para os humanos, o que para nós é uma avaliação empobrecedora, antropocêntrica.

De toda forma, é patente que existe um enorme catálogo de espécies ainda a ser composto pelos humanos, superando em muito o catálogo das cerca de 2,2 milhões de espécies identificadas e reconhecidas oficialmente nos últimos 250 anos pelo cânones científicos. Já que estamos lidando também com a visão antropocêntrica, é pertinente lembrar que, mesmo entre as espécies já catalogadas, muitas podem ter utilidades ainda desconhecidas para a nossa espécie. Outras não terão utilidade alguma, mas isso não lhes rouba valor do ponto de vista da importância per se da biodiversidade.

Mesmo submetidas a milênios de extração de baixa tecnologia e a uns 300 anos de pesquisas comerciais e científicas sistemáticas, o conhecimento sobre o potencial de "utilidades" existentes nas florestas tropicais brasileiras está longe de se exaurir. As espécies desconhecidas e/ou não utilizadas têm maior chance de sobreviver (até serem descobertas e estudadas) se as florestas nas quais evoluíram forem preservadas ou se pelo menos as florestas forem modificadas pela ação humana extrativista. O mesmo vale para as espécies conhecidas, ainda que incompletamente.

A relevância deste argumento muito citado em defesa do extrativismo não pode ser exagerada. Grandes monoculturas e pastagens, extensas operações de corte raso de árvores, a formação de lagos atrás de barragens de hidrelétricas e outros usos das terras florestadas implicam na erradicação quase completa de grandes extensões das formações vegetais nativas e dos ambientes que elas formam para muitas modalidades de vida. Destroem o ambiente no qual se formou a biodiversidade e onde os seus componentes evoluíram por longos períodos de tempo. Produtos ou matérias-primas de todos os tipos, para muitos ramos da atividade humana, podem estar estocados nas florestas preservadas ou mantidas sob regime extrativista.

Não obstante, pensamos que os parques nacionais, reservas biológicas e outras unidades de conservação de proteção integral, que implicam no não uso ou no uso apenas "indireto" dos componentes da biodiversidade, são as melhores alternativas para salvaguardar esse patrimônio. Depois deles, 
a melhor opção é o extrativismo - praticado fora ou dentro de RESEXs, PAFs, RDSs, PDSs e PAEs acima mencionados.

Por outro lado, deve-se levar em conta que o "tesouro oculto" da biodiversidade ainda desconhecida contida nas florestas tropicais úmidas não está imediatamente disponível. Como sugere a própria metáfora do tesouro (termo muito usado pelos defensores antropocêntricos da biodiversidade), os componentes "úteis" da biodiversidade estão misturados com ou "soterrados" por uma grande massa de componentes "inúteis". É o mesmo que acontece com pedras preciosas ou pepitas de ouro - pode-se suspeitar que elas existem num determinado local, mas é preciso trabalhar muito para separá-las da terra e da água que as cobre. Não se encontra um tesouro sem um mapa, cavando a esmo, e os componentes "úteis" da biodiversidade não são assinalados nos mapas, mesmo se existirem.

Quanto mais componentes "inúteis" (ou aparentemente "inúteis") houver, mais trabalhosas e caras são a "triagem" e a identificação dos componentes "úteis". As descobertas dos "tesouros ocultos" das florestas tropicais, uma vez ocorridas, exigem necessariamente longos períodos para provar que os seus potenciais são concretos: estudos, identificação, experimentação e aplicação. Nessas etapas os extratores terão um papel pequeno, já que elas envolverão cientistas altamente preparados, institutos de pesquisa, laboratórios e equipamentos caros, protocolos complexos de pesquisa, empresas comerciais, elevados investimentos, órgãos de controle e fomento, procedimentos de patenteamento, negociações comerciais e diplomáticas entre países e blocos de países, etc. O fato de o papel dos extratores ser pequeno não justifica, evidentemente, que eles sejam marginalizados quando as descobertas gerarem benefícios concretos.

\subsection{As ciências naturais e técnicas} contemporâneas têm interesse especial pelo futuro das florestas tropicais protegidas pelo extrativismo

Vários ramos da ciência natural (botânica, zoologia, microbiologia, ecologia, genética, agronomia, zootecnia, engenharia florestal, engenharia ambiental e correlatas) têm nas florestas tropicais remanescentes uma "fronteira" de expansão de grande importância. O futuro dessas ciências, nas suas versões aplicadas e básicas, depende em boa parte do futuro das florestas tropicais como repositórios de genes, tecidos, organismos, sistemas, comunidades e processos evolutivos que (i) só existem nelas e (ii) são impossíveis de reproduzir em laboratório e mesmo no campo. Essas ciências, especialmente nas nações ricas, são em si mesmas poderosos conglomerados financeiros, técnicos e de recursos humanos (cientistas, pesquisadores, técnicos, universidades, fundações de pesquisa, editoras, publicações, órgãos de fomento, estudantes, laboratórios públicos e particulares, empresas de biotecnologia e engenharia genética, patenteamentos, etc.). Por isso, muitos cientistas naturais são membros importantes da frente ampla global a favor da pesquisa, da preservação e do uso racional de florestas tropicais de todo o mundo.

Grupos de extratores das florestas tropicais têm servido (explicitamente ou não) como informantes e identificadores preliminares de alguns produtos e processos florestais úteis, tanto para instituições científicas quanto para empresas de diversos ramos. É claro que os extratores e o seu saber folk só sobreviverão enquanto houver florestas de pé e enquanto comunidades humanas viverem nelas. Mas, mesmo enquanto há florestas de pé, os extratores podem ser deslocados de suas atividades 
propriamente extrativas para se dedicarem a outras ocupações, por várias causas: expulsão ou migração das suas áreas tradicionais de ocupação, perda de valor dos seus produtos extrativos ou engajamento em outras ocupações.

Não é casual, portanto, que muitos cientistas naturais (e sociais) expressem simpatia pela causa do extrativismo de baixa tecnologia, tanto na forma de apoio político e financeiro aos extratores quanto nas formas de assistência técnica ou de apoio político. Mesmo reconhecendo as limitações socioeconômicas do extrativismo (e em alguns casos ignorando-as) e mesmo admitindo que o extrativismo provoca alterações na biodiversidade, muitos cientistas e ativistas consideram que ele é a melhor opção para preservar as numerosas formas de vida características das florestas tropicais úmidas. Os que se julgam mais pragmáticos acham também que as reservas extrativistas podem "se sustentar", ou seja, fazer a floresta produzir bens comercializáveis sem ser destruída - essa posição é comumente traduzida na expressão “fazer a floresta de pé produzir". Isso é construído como uma "justificativa” mercadológica para reservas extrativistas e afins, uma justificativa que evidentemente não se aplica a parques nacionais e a outros tipos de áreas que excluem atividades produtivas. Os mais românticos, por outro lado, julgam que o saber folk dos extratores é superior ao - e não precisa do apoio do - saber científico.

\subsection{O extrativismo não é necessariamente sustentável, econômica ou ecologicamente}

Afirmar que toda forma de extrativismo é ecológica e economicamente sustentável é errado, embora isso seja defendido por muitos simpatizantes do extrativismo e das chamadas "populações tradicionais" extratoras. A sustentabilidade estri- tamente ecológica do extrativismo não é fácil de ocorrer, nem de comprovar. Mesmo se comprovada, ela não garante necessariamente um bom nível de vida para os extratores.

Nesse particular, não há espaço para romantismo. Muitas formas de extração de baixa tecnologia foram e são destrutivas da base de recursos. Num texto de abrangência global, Fernandez e Araújo reveem e resumem uma extensa literatura que correlaciona extinções de numerosos integrantes da megafauna com a chegada de grupos de caçadores-coletores Homo sapiens a diferentes partes do planeta, em tempos pré-históricos (Fernandez \& Araújo, 2012). Um exemplo clássico em escala local e de tempos recentes é o das árvores de caucho (Castilla ulei) da Amazônia, que produzem um tipo de látex. A sua exploração se dá pela sua derrubada, feita às vezes pelos mesmos seringueiros que exploram a seringueira de forma supostamente sustentável. Mesmo no caso da extração do látex das seringueiras, de novo elas podem ser exploradas até a exaustão em poucas temporadas, ou por décadas, dependendo da intensidade e da tecnologia aplicadas. O romance $A$ Selva, do português Ferreira de Castro (1898-1974), publicado em 1930, retrata um personagem candidato a seringueiro, recém-chegado a um seringal amazônico. Ele nada sabia sobre como "sangrar" a seringueira. Por isso, ele é vigiado de perto pelos colegas mais antigos, que o ensinam a tirar o látex das seringueiras, sem matá-las. O significativo apelido dado pelos seringueiros antigos a esses seringueiros novos era o de "brabos", pois que matavam as seringueiras, sem querer (Castro, 1943). Outro exemplo amazônico clássico de sobre-exploração de recursos naturais por populações locais é o dos ovos de quelônios em tempos coloniais e pós-coloniais (Costa, 2012). Indígenas de muitas partes da América do Norte, induzidos por comerciantes e intermediários co- 
nectados a amplos mercados nacionais e europeus, dizimaram implacavelmente populações de dezenas de espécies de animais portadores de pelagem (pelts), causando numerosas extinções locais. As peles eram usadas para fabricar roupas, luvas, botas e chapéus usados por norte-americanos e europeus como proteção contra o frio dos invernos rigorosos. Os nomes comuns de alguns desses animais dão ideia da abrangência da caça direcionada ao mercado (da qual participavam também não indígenas): castor, rato almiscarado, texugo, raccoon (mão pelada), lontra comum, lontra marinha, carcaju, bisão, urso, alce, veado, lobo, coiote, furão, weasel (doninha), coelho e até esquilo (Martin, 1978; Dolin, 2010).

No entanto, a questão é ainda mais complexa, pois uma atividade extrativa que seja ecologicamente sustentável (ou seja, os ciclos reprodutivos naturais de plantas e animais são conhecidos, respeitados e mantidos) pode ser economicamente inviável. Isso se dá por causa de vários fatores discutidos acima: geração insuficiente de renda, estímulos para coletar excessivamente, competição de produtos naturais semelhantes (selvagens ou domesticados) ou de produtos sintéticos, ou a simples falta de mercado.

Se a viabilidade econômica não é alcançada via mercado, pode-se tentar - e já foram tentadas - alternativas ao funcionamento puro dos mecanismos de mercado. Um programa de sustentação ou complementação de preços de produtos extrativos, por exemplo, deve propiciar aos extratores valores suficientes para dar conta da sua reprodução familiar. Deve funcionar também como um fator "aliviador" das pressões humanas sobre o meio natural. Maciel et al. (2010) desenvolveram uma metodologia de cálculo de preços baseada na dinâmica de dois produtos extrativos florestais não madeireiros (borracha e castanha), adotando como limite a remuneração específica por produto e levando em conta a capacidade reprodutiva dos dois bens. O objetivo da metodologia é desestimular os extrativistas a ultrapassar os limites ecológicos e históricos de produção de cada bem. O estudo foi desenvolvido na RESEX Chico Mendes, no Acre. A proposta dos pesquisadores foi a de atualizar o valor pago com base na lei estadual acreana $\mathrm{n}^{\circ}$ 1.277, de 13 de janeiro de 1999 (conhecida como "Lei Chico Mendes"), para R \$22,00 por hectare de floresta não desmatada. No caso da borracha, os autores sugeriram que o subsídio fosse reajustado de $\mathrm{R} \$ 1,40$ para $\mathrm{R} \$ 10,89 / \mathrm{kg}$ (ver Humphries et al., 2012).

Uma outra via para compensar as insuficiências do mercado (ou para neutralizar os estímulos do mercado à sobrecoleta) é a da política de subsídios e/ou de reservas de mercado. Um exemplo menos conhecido do que deveria ser - e que foi mencionado acima - é o seguinte: a própria existência física do grupo social de seringueiros no Brasil para além dos anos 1910 dependeu de décadas de uma política federal tripartite: (i) reserva de mercado (restrições às importações de borracha), (ii) subsídios aos preços da borracha coletada na Amazônia, e (iii) obrigação de certas indústrias instaladas no Brasil (de pneumáticos, por exemplo) de adquirir a borracha nativa da Amazônia (Dean, 1987). O período de validade dessa política venceu na década de $1980 \mathrm{e}$ não foi renovado. Esses subsídios eram tão antigos e estavam tão rotinizados que o seu fim iminente era desconhecido até por líderes e simpatizantes dos seringueiros.

Os agricultores familiares brasileiros têm acesso ao Programa de Garantia de Preços para a Agricultura Familiar - PGPAF. ${ }^{12}$ A relevância desse

12 Portaria 34, Ministério de Desenvolvimento Agrário, de 5 de junho de 2014. 
programa para o nosso texto reside no fato de que entre os produtos-alvo da medida estão alguns bens extrativos, tais como açaí, babaçu (amêndoa), borracha, cacau (amêndoa), pequi e piaçava (fibra). No que se refere à borracha natural extraída, o bônus foi pago em sete estados: Acre, Amazonas, Pará, Roraima, Tocantins, Maranhão e Mato Grosso. Recorde-se o mecanismo, mencionado acima, de subsídios à borracha natural extraída do governo do Acre, que funciona com base na Lei ${ }^{\circ} 1.277$, de 13 de janeiro de $1999,{ }^{13}$ alterada pela Lei $n^{0} 1.427$, de 27 de dezembro de $2001 .{ }^{14} \mathrm{O}$ governo estadual faz pagamentos por quilo de borracha extraída para os seringueiros cadastrados por associações ou cooperativas. A função do subsídio é complementar os baixos preços da borracha.

Uma política correlata foi instituída pelo governo estadual do Amapá em 1997. O governo passou a comprar, a preços garantidos, toda a produção de castanha coletada na RDS do Rio Iratapuru (estadual). Houve também financiamento aos castanheiros para a aquisição e montagem de equipamentos industriais de beneficiamento da castanha (torrefação e moagem). Essa parte da produção amapaense de castanha foi aproveitada no programa estadual de merenda escolar (Vilhena, 2001).

Duke (1991), simpatizante do extrativismo de baixa tecnologia, propõe que os consumidores de produtos extrativos de florestas tropicais devem estar dispostos a pagar uma "sobretaxa" para ajudar a sustentar os extratores frente aos seus concorrentes "modernos". Esta é uma "solução de mercado", por via de subsídios privados difusos, que pode ou não se relacionar a políticas públicas. Esse tipo de subsídio privado está muitas vezes embutido nos preços relativamente mais altos pagos voluntariamente pelos consumidores de certos produtos "alternativos" ou "naturais", mas ele pode ser associado a esquemas de certificação e de comércio justo apoiadas por políticas públicas e por acordos entre organizações de produtores, revendedores e consumidores. Outros esforços e iniciativas no sentido de combinar a viabilidade econômica e a viabilidade ecológica da produção extrativa de bens oriundos das florestas tropicais são descritos em Anderson \& Clay (2002), Enriquez et al. (2003; 2009).

Há, portanto, muitas variáveis a considerar para avaliar a sustentabilidade ecológica e econômica da extração de produtos florestais. Os seringueiros brasileiros alegam conhecer e respeitar os ciclos reprodutivos dos bens que exploram, mas isso precisa ser verificado caso a caso, com inputs de cientistas e técnicos. O saber folk e o conhecimento científico podem ser combinados para esse fim, mas a verdade é que para muitos produtos a sustentabilidade de longo prazo ainda é apenas um ideal ou uma afirmação sem fundamentação. Muita pesquisa e muita experimentação precisam ser feitas para garantir que determinado produto esteja sendo extraído de forma ecológica e economicamente sustentável.

Não será demais lembrar que, mesmo depois de a prática ecologicamente sustentável de extração de um produto ser claramente determinada, as pressões da competição podem levar ao abandono dessa prática e à exaustão do recurso por motivo de sobre-exploração. Nesse cenário, nada fictício ou fantasioso, a perspectiva imediata de rendimento econômico derrotaria o objetivo de longo prazo da sustentabilidade ecológica. Afinal de contas, a lógica mais profunda da economia de mercado é produzir excedentes trocáveis e liberar a produção econômica das restrições naturais.

13 Disponível em: <http://www.al.ac.leg.br/leis/wp-content/uploads/2014/09/Lei1277.pdf>. Acesso em: 29 dez. 2014.
14 Disponível em: <http://www.al.ac.leg.br/leis/wp-content/uploads/2014/09/Lei1426.pdf>. Acesso em: 29 dez. 2014. 


\subsection{Quantas pessoas podem ser sustentadas pelas economias extrativas?}

Uma das poucas certezas a respeito de economias extrativistas de baixa tecnologia em florestas tropicais é que elas só conseguem sustentar populações pequenas e/ou de baixa densidade populacional. Isto é certo porque (i) as taxas de exploração sustentada dos recursos têm de ser ajustadas aos prazos de reprodução natural dos recursos e (ii) a distribuição natural dos recursos vegetais e animais nessas florestas tropicais é tipicamente esparsa (o que é resumido na expressão "muitas espécies por unidade de área, mas poucos espécimes"; isso se refere a árvores, mas vale para outros seres). $\mathrm{O}$ extrativismo de flora e fauna em quase todos os lugares é por definição extensivo, e não intensivo. Por isso, ele sustenta populações relativamente esparsas, distribuídas por áreas relativamente grandes. Não vemos nisso uma desvantagem ou um "pecado" do extrativismo, mas deve ficar claro que ele não é uma opção viável para sustento direto de populações grandes e densas.

Pensando no extrativismo como um setor entre outros de uma economia diversificada e complexa, como é o caso no Brasil, constatamos que existem outros setores que também empregam/sustentam relativamente poucas pessoas. A mineração empresarial e a extração petrolífera (para ficarmos no setor extrativista de alta tecnologia), por exemplo, são intensivas de tecnologia e mecanização e não de mão de obra; mas isso é "compensado" pelos salários geralmente altos dos seus empregados e pelas múltiplas conexões que as empresas desses setores estabelecem com outras empresas e com os consumidores de seus produtos. Em alguns outros setores da economia, a busca pela redução da mão de obra é também comum. Nas instituições financeiras brasileiras (bancos, principalmente), por exemplo, a automação e o uso de recursos de computação e internet fez com que o número de empregados diretos caísse a menos da metade nos últimos 20 anos. Enfim, empregar/sustentar números reduzidos de pessoas não é um traço exclusivo de economias extrativistas.

Alguns críticos do extrativismo destacam que os rendimentos modestos e o caráter extensivo das áreas e reservas extrativistas são capazes de sustentar apenas uma população pequena e esparsa e em níveis muito modestos, quando não de pobreza. É verdade que as áreas e reservas extrativistas (i) tendem a ter populações residentes pequenas e esparsas e (ii) precisam ter grandes dimensões. Isso obviamente traz para elas implicações desfavoráveis em termos (i) de competição com outros usos do solo e dos recursos e (ii) de regularização fundiária.

Outras considerações cabem neste tópico. Se é certo que o extrativismo de baixa tecnologia "sustenta pouca gente" em relação ao tamanho das áreas necessárias para alcançar viabilidade, é certo também que a criação extensiva de gado que foi durante duas décadas a forma preferencial e oficialmente sancionada de ocupar a Amazônia e o Centro-Oeste brasileiros - também emprega pouca gente por unidade de área, em alguns casos menos que o extrativismo. Ou seja, a introdução de fazendas de gado em trechos recém-desmatados de floresta amazônica ocupada por extratores causou em muitos casos a perda líquida de empregos.

Por sua vez, grandes empreendimentos rodoviários, mineradores, hidrelétricos e petrolíferos sistematicamente se justificam com a alegação de criar muitos empregos. No entanto, isso só é verdade na fase de construção, pois esses empreendimentos são intensivos de capital e por isso criam relativamente poucos empregos permanentes nas suas fases ope- 
racionais, principalmente para as populações locais. Uma grande hidrelétrica que mobiliza milhares de empregados na sua construção pode ser operada por apenas algumas centenas de empregados, muitos dos quais altamente qualificados e não recrutados entre as populações locais. Ainda assim, permanece o fato de que as reservas extrativistas, mesmo bastante disseminadas na Amazônia e fora dela, não sustentam grandes massas de pessoas, nem garantem altos níveis de vida aos extratores.

\subsection{Qual a compatibilidade entre as reservas extrativistas e a reforma agrária?}

Essa é uma questão propriamente política e correlata à anterior: as reservas extrativistas e unidades similares, de tamanho relativamente grande e que acomodam uma população relativamente pequena, seriam uma "injustiça" cometida contra os agricultores sem terra de outras regiões brasileiras? Esta questão, muito debatida nos fins dos anos 1980 e no início dos anos 1990, envelheceu em virtude do forte avanço da reforma agrária (ou colonização) em todo o Brasil e na própria Amazônia, ocorrida a partir de 1995. No entanto, o seu exame é cabível, pois reservas extrativistas e políticas conexas continuam a atender um público diferente que reivindica e vem a ser beneficiado por políticas de reforma agrária e colonização.

Esse é um caso exemplar em que um fato incontroverso (o extrativismo não emprega muitas pessoas - ver item 4.11, acima) é ligado a outro fato (a falta - agora superada em parte - de reforma agrária), mas de forma incorreta. No entanto, essa crítica às reservas extrativistas - nos anos 1990 ela era veiculada até por ativistas da reforma agrária - peca(va) por ignorar o óbvio: as reservas extrativistas são em si mesmas uma reforma agrária no contexto diferenciado da Amazônia. Elas são concessões de terras públicas feitas a associações de produtores rurais pobres, um fato até então inédito nas políticas fundiárias coloniais, imperiais e republicanas do Brasil. É uma política radicalmente nova no Brasil, em qualquer região, e que, a nosso ver, deveria ter sido defendida por todos os partidários de reforma agrária e da justiça social.

Conforme mencionado acima, esse quadro mudou nos últimos 20 anos, como consequência de uma grande onda de reforma agrária ocorrida no Brasil a partir de 1995. Como ela foi feita em sua maior parte em terras públicas, rigorosamente ela seria mais bem denominada de colonização, mas, para efeitos do nosso texto, essa distinção não é crucial. Em fins de 2014, o INCRA relatava a existência de mais de 9.000 assentamentos de reforma agrária de diversos tipos e em diversas fases de criação (criados, consolidados, em consolidação, em estruturação, em instalação, etc.). O número de famílias beneficiadas e a beneficiar (incluindo os assentamentos nas fases preliminares de criação) chegava a 947.000 , em torno de 5 milhões de pessoas. Se todos os assentamentos forem concretizados, a área conjunta deles chegará a cerca de $874.960 \mathrm{~km}^{2}$, mais de $10 \%$ do território nacional (INCRA, 2014). Le Tourneau \& Bursztyn (2010) mostram que a maior parte dessa adiada reforma agrária brasileira incidiu sobre a Amazônia Legal e as suas florestas tropicais úmidas. É pertinente destacar, como fizeram esses autores, que tanto os governos militares autoritários quanto os mais recentes governos civis democráticos elegeram a Amazônia como a região preferencial para as suas políticas de reforma agrária. Isso mostra, entre outras coisas, que tanto os militares quanto os civis no poder consideram a floresta amazônica e a sua biodiversidade como sacrificáveis em face do 
que entenderam e entendem como imperativos do desenvolvimento e da justiça social. No entanto, os governos civis superaram amplamente os governos militares em números de famílias assentadas na região.

Não é causal, portanto, que o MMA e o INCRA se engajem quase anualmente em polêmicas sobre os altos índices de desmatamentos rasos registrados nos assentamentos da reforma agrária na Amazônia e sobre a falta de licenciamento ambiental de muitos desses assentamentos (INCRA, 2014). Quer esses assentamentos desmatem muito ou pouco, não há dúvida de que desmatam. Para os nossos fins, isso indica que eles são radicalmente distintos do que são ou devem ser as reservas extrativistas e unidades similares, ou seja, os assentamentos não são criados com um compromisso com a noção de fazer a "floresta em pé" produzir. O ponto mais importante aqui é que nas duas últimas décadas as reservas e as comunidades extrativistas não estão sozinhas no que toca aos usos da terra praticados pelos trabalhadores rurais mais pobres ou remediados da Amazônia. Na nossa visão, os estudiosos e os formuladores de políticas têm que continuar a distinguir os extratores dos assentados da reforma agrária e a lidar separadamente com as políticas públicas que afetam uns e outros.

Não temos informações sobre conflitos sistemáticos entre beneficiários de reservas extrativistas, de um lado, e beneficiários da reforma agrária, de outro, na Amazônia ou fora dela. Aparentemente, em escala macro, os dois grupos estão sendo contemplados em seus direitos e em suas pretensões, sem atritos mútuos sérios. De toda forma, não vemos por que os extratores amazônicos, que se organizaram pelas suas próprias forças, teriam alguma obrigação de moderar as suas reivindicações pelas reservas extrativistas pelo fato de não ter ocorrido até a década de 1990 uma reforma ou colonização agrária ampla no resto do Brasil ou mesmo na própria Amazônia. É uma hipótese factível que os tipos "diferenciados" de assentamentos criados pelo INCRA - os PAFs, RDSs, PDSs e PAEs, mencionados em seção anterior do presente texto - foram em parte inspirados nas reservas extrativistas, o que indicaria um grau de convergência entre políticas distintas voltadas para o mundo rural amazônico.

O fato é que (i) a reforma agrária ocorreu e incidiu principalmente sobre a Amazônia e (ii) ela parece conviver bem com as reservas extrativistas. Permanece a distinção importante, no entanto: as reservas foram concebidas com o objetivo "inovador" de defender o estilo de vida de um grupo social particular, os extratores amazônidas, e aproveitar/ proteger os potenciais ambientais e produtivos de terras florestadas úmidas, enquanto a reforma agrária, dentro ou fora da Amazônia, foi concebida para atender os interesses de um grupo distinto, o dos agricultores familiares sem terra de todo o país.

\subsection{Os trabalhadores rurais que migram de outras regiões para a Amazônia são atraídos por atividades extrativistas?}

As atividades extrativistas seriam capazes de incorporar ou atrair levas de migrantes transferidos de outras regiões para áreas florestadas amazônicas por causa da falta de reforma agrária em suas regiões de origem? Embora essa pergunta também tenha envelhecido por causa da forte incidência da reforma agrária na região amazônica e fora dela nos últimos 20 anos, ainda cabe perguntar: o extrativismo como modo de produzir é atraente para os agricultores familiares oriundos de outras regiões? Esta é uma questão política derivada do item anterior. Ela leva em conta não apenas as marcantes 
diferenças entre extrativismo e agricultura, mas as diferenças entre estilos de vida das populações rurais das várias regiões do Brasil.

Muitos estudiosos, técnicos ativistas e políticos defenderam e continuam a defender a migração dos trabalhadores rurais sem terra de outras regiões para a Amazônia como forma de alcançar justiça social, de desmontar tensões nessas outras regiões e de "ocupar" a Amazônia, posição que, como vimos, prevaleceu tanto sob governos militares quanto sob governos civis. Coloquemos a questão em outros termos: os migrantes que foram ou vão para a Amazônia como assentados de reforma agrária ou de colonização desejam ser extratores? Parece-nos que a resposta é negativa. Nossa hipótese é que esses migrantes não querem viver em áreas isoladas, dentro de florestas densas, coletando produtos que lhes são estranhos. O projeto deles é antes cultivar plantas e criar animais conhecidos, o que implica necessariamente em desmatar trechos florestados e instalar culturas comerciais e de subsistência; querem também estradas e outros itens de infraestrutura para viabilizar a sua produção. Via de regra, as paisagens agropecuárias de onde provêm esses migrantes foram desmatadas há décadas ou mesmo há séculos e são dotadas de alguns itens de infraestrutura. Eles desejam reproduzir essas paisagens e ter acesso a essa infraestrutura.

Estamos afirmando, portanto, que as reservas extrativistas servem para manter o estilo de vida dos extratores habituados com um estilo extrativista de vida e não para transformar agricultores em extratores (ou vice-versa), embora muitos extratores contemporâneos combinem atividades extrativistas com atividades agropecuárias. Conceitualmente, portanto, as reservas e atividades extrativistas não nos parecem compatíveis para receber o influxo de migrantes cuja primeira preocupação - legíti- ma e legal - seja desmatar, plantar cultivos e criar animais. Essa "seletividade" não deve ser tomada de forma absoluta, porém, já que as reservas extrativistas não abrangem toda a Amazônia e que os assentamentos para agricultores familiares se disseminaram amplamente pela região. Talvez ainda haja margem para mais assentamentos agropecuários, mas a área conjunta das reservas extrativistas não tende a crescer continuamente, mesmo porque nem todos entre os trabalhadores rurais amazônidas são extratores.

\subsection{Qual é a viabilidade política do extrativismo na Amazônia?}

O extrativismo vegetal e animal de baixa tecnologia é um uso da terra que exclui, limita severamente ou convive conflituosamente com quase todas as outras atividades que usam recursos naturais amazônicos - agricultura familiar e empresarial, criação de gado, mineração, operações madeireiras, plantio comercial de árvores, hidrelétricas, exploração de petróleo e gás natural, etc. Esse fato "duro" propicia a discussão do tema de sua viabilidade política frente a essas atividades competidoras. $\mathrm{O}$ volume de interesses investidos e organizados em torno dessas outras atividades é enorme. Além disso, esses interesses são legais e legítimos, pois várias forças sociais expressivas têm interesse nelas - empresários, donos de terras (pequenos e grandes), trabalhadores rurais e urbanos, políticos locais e nacionais, planejadores, investidores, consumidores empresariais e individuais de energia, minérios, alimentos e de produtos madeireiros, etc.

A base social e o poder organizacional do extrativismo, por outro lado, residem principalmente numa classe rarefeita de trabalhadores ru- 
rais pobres. Essa classe conseguiu algum grau de organização apenas recentemente, com apoio de ativistas do ambientalismo e de cientistas, ambos relativamente carentes de outras bases sociais ou mesmo de aliados na região amazônica ou nas áreas de outros biomas sujeitas ao extrativismo. Desde a década de 1990, é verdade, alguns políticos que apoiam o extrativismo amazônico alcançaram projeção e influência em seus estados e até no plano nacional - João Capiberibe no Amapá, os irmãos Viana, Marina Silva e aliados no Acre, e (em parte) Eduardo Braga e os seus aliados, no Amazonas. O esforço dos seringueiros e outros extratores para se manterem unidos é dificultado pela sua dispersão e pobreza. As suas organizações tiveram vitórias importantes - criação de 90 reservas extrativistas, regularização fundiária, obtenção de financiamentos e parcerias para atividades de processamento e industrialização de alguns produtos, acordos e parcerias técnicos e comerciais, subsídios - mas elas dependeram e em grande parte dependem de apoios locais e externos cuja continuidade é incerta.

A coalizão favorável ao extrativismo de baixa tecnologia, nascida em meados dos anos 1980 , persistiu e se ampliou, mas as outras forças sociais também se fortaleceram e construíram argumentos e instrumentos com que defendem muito bem os seus próprios interesses. Um exemplo marcante disso nos últimos anos é o do agronegócio. A intimidação e a violência física contra os líderes dos extratores não é a mais eficaz nem a única ameaça ao extrativismo, e sim a força organizada e econômica, individual e conjunta dos grupos sociais que defendem outros usos do solo. Além da sustentabilidade econômica e ecológica, portanto, os seringueiros e outros extratores precisam manter viva a sua eficácia propriamente política. Conservar as floras nativas e vencer no mercado são necessários, mas não bastam.

\subsection{Existem barreiras culturais ao extrativismo}

Políticos profissionais, detentores de cargos técnicos e políticos nos diversos níveis de poder e grande parte dos líderes atuantes em outros setores sociais nasceram e cresceram no contexto de uma economia brasileira urbano-industrial em crescimento acelerado. Esses líderes se formaram num ambiente favorável à modernização e aprenderam a valorizar a agricultura modernizada, a urbanização, a industrialização, a alta tecnologia, a produtividade, a educação formal e a produção para o mercado - tudo o que falta ou é escasso no extrativismo de baixa tecnologia. Nesse contexto, as atividades "tradicionais" rurais, inclusive o extrativismo de baixa tecnologia, perderam peso social e econômico e se tornaram menos visíveis.

A grande maioria desses líderes, inclusive aqueles das regiões e estados onde o extrativismo tem maior representatividade social e produtiva, apoia uma economia sedentária, agroindustrial, urbanizada. A atuação de políticos como Marina Silva e João Capiberibe e aliados relativiza essa afirmação, mas não a invalida. $\mathrm{O}$ extrativismo de baixa tecnologia tende a parecer a muitos líderes "retrógrado", incompatível com a economia de uma "potência mundial", de um país “emergente". Como os seringueiros e demais extratores formam grupos sociais pequenos e pobres, geograficamente pulverizados e historicamente disenfranchised (carentes de direitos políticos plenos), eles tendem a ser ouvidos por esses líderes por último, quando são ouvidos. Sem o apoio de cientistas e ambientalistas, eles talvez não tivessem sido ouvidos na década de 1980 , nem com a ascensão e a morte de Chico Mendes. Dificilmente os extratores deixarão de ocupar um nicho "negativo" no imaginário dos representantes 
políticos que tenham outras bases sociais e eleitorais. Dificilmente os líderes dos próprios extratores alcançarão uma força política equivalente à dessas outras forças sociais. As reservas extrativistas e o próprio ideal de um extrativismo de baixa tecnologia podem sofrer as consequências negativas disso.

\subsection{Uma economia extrativista conduz à justiça social?}

Este é um tópico normativo, valorativo, mas subjacente a - e presente em - quase todos os tópicos anteriores. Argumentos apresentados no item 4, acima, indicam que as economias extrativistas formam sociedades com uma larga base de extratores pobres, um pequeno estrato de intermediários (comerciantes varejistas, transportadores e fornecedores) e um ápice mínimo de atacadistas, financiadores e processadores ricos. Essa achatada pirâmide promete poucas perspectivas de justiça social. Como a agregação de valores aos produtos extrativos ocorre em outras áreas geográficas e/ ou é feita por outros grupos sociais que não os extratores, as sociedades e as regiões propriamente extrativistas alcançam pouca diversificação e prosperidade. Não surgem classes numerosas e amplas de trabalhadores industriais, profissionais liberais, empregados de escritórios e serviços, estudantes de cursos profissionais ou universitários. Como diz Freudenberg (1992), as comunidades dependentes de recursos naturais ficam como que "viciadas" no extrativismo e na sua própria estrutura social rigidamente estratificada, simplificada e injusta e nas atividades produtivas que geram essa estrutura.

É correto dizer, portanto, que o perfil social "injusto" da Amazônia contemporânea foi formado e é em parte mantido pelo próprio extrativismo, mais exatamente pelo sistema de aviamento usado para administrar o extrativismo. A base comunitária das reservas extrativistas pode ajudar a internalizar algumas funções de intermediação comercial e de beneficiamento, funções essas que o sistema de aviamento reservava a outros grupos sociais que não os próprios extratores. Mas, dificilmente essa base comunitária significa a internalização das outras etapas de agregação de valor e finalização dos produtos, pois que tipicamente faltam nas regiões e comunidades extrativistas infraestrutura, mão de obra, know-how, maquinário, conexões comerciais e financiamento para instalar etapas industriais, comercialização, marketing, etc. Dessa forma, é preciso reconhecer que (i) o extrativismo alcança alguma força apenas na sua própria região de ocorrência e (ii) não tende a gerar um nível de renda, um grau de divisão do trabalho, um perfil de distribuição de renda e uma dinâmica de agregação local de valor que levem ao desenvolvimento, à diversificação produtiva e social ou à "justiça social". Isso não significa que o extrativismo seja o único modo de produzir uma sociedade "injusta", pois sociedades injustas existem também em regiões e sociedades em que o extrativismo tem peso mínimo ou desapareceu há muito tempo.

\section{Considerações finais}

A nossa visão geral sobre o extrativismo de baixa tecnologia se delineou ao longo da discussão dos 16 tópicos da seção anterior. Nesta seção final, (i) recapitulamos essa nossa visão, (ii) recuperamos os problemas básicos que enxergamos para a viabilidade do extrativismo de baixa tecnologia e (iii) sugerimos linhas de pesquisa e de ação que podem ajudar a pensar esse extrativismo.

Pensamos que o extrativismo de baixa tecnologia pode e deve continuar a ser um "modo de 
produção" que ofereça uma vida digna e substantiva para uma parte substancial dos trabalhadores rurais amazônicos e de outras regiões nas quais o extrativismo ainda exista. Mais precisamente, pensamos que o extrativismo só alcançará essa meta se for feito em bases (i) comunitárias, (ii) ecologicamente sustentáveis e (iii) economicamente viáveis. $\mathrm{Ou}$ seja, o "modo de produção" extrativista nos parece viável e desejável, mas precisa de uma base social organizada e tem que mostrar resultados.

Esses três requisitos se desdobram em cinco pontos:

(i) Os empreendimentos extrativos de base comunitária que visem a sustentabilidade devem ser levados a cabo em terras públicas cobertas por floras nativas (dos diversos biomas) especialmente designadas para esse fim. Deve ser mantido o formato existente (principalmente o das reservas extrativistas) de cessão de terras públicas a comunidades residentes ou organizações profissionais de extratores. Essas terras podem se localizar também dentro das florestas nacionais e áreas de proteção ambiental, categorias de unidades de conservação que permitem a exploração de recursos, ou na periferia de tipos mais restritivos de unidades de conservação, como parques nacionais, reservas biológicas e estações ecológicas. Nesse segundo caso, elas devem ter a função complementar de proteger essas unidades contra formas intensivas de uso dos recursos naturais.

(ii) As reservas extrativistas devem ser manejadas de forma prudente e planejada, tanto econômica quanto ecologicamente, se quiserem se aproximar de um patamar de sustentabilidade. Para tanto, o seu manejo deve combinar (1) atividades de mercado com atividades de subsistência e (2) conhecimentos folk ("tradicionais") com conhecimentos científicos. Deve haver um saudável realismo comercial para evitar que as reservas se abalem com ciclos de altos e baixos rendimentos ou estagnem num emaranhado de subsídios diretos ou indiretos. Entre outras coisas, isso implica que cada comunidade de extratores explore uma gama variada de produtos, para tirar partido dos ciclos não coincidentes de reprodução natural dos bens e de oportunidades comerciais que não sejam apenas sazonais. Evidentemente, produzir para o mercado provoca tensões bem conhecidas na cultura das comunidades de extratores. Essas tensões são o preço inescapável que qualquer grupo social paga para ingressar no mercado ou para alcançar uma inserção mais profunda nele. De outro lado, a produção de valores de uso (para subsistência) não deve ser desprezada nem eliminada, pois eles amenizam dificuldades criadas pelas previsíveis oscilações das atividades extrativas voltadas para o mercado.

(iii) As reservas extrativistas devem se sujeitar a "auditorias" governamentais (do ICMBio) e independentes (de técnicos e ONGs), dando livre acesso às informações sobre atividades, tecnologias e planos de produção, para verificar se os termos da cessão estão sendo cumpridos. Instituições de assistência técnica devem lhes prestar o devido apoio. Cientistas e instituições científicas também devem se candidatar a monitorar independentemente e apoiar as reservas extrativistas, tal como fazem com outras formas de uso de recursos naturais amazônicos. Infelizmente, conhecemos pessoalmente mais de um cientista ou técnico que, apesar de decepcionados com este ou aquele grupo de extratores que optam por abrir pastos para criar gado, ou por vender toras, ou por desmatar ilegalmente trechos florestados de suas reservas, toleram essas flagrantes violações dos termos de cessão das terras de suas reservas.

(iv) As reservas extrativistas precisam buscar agressivamente forward linkages, ou seja, ligar as suas atividades de extração com atividades 
industriais, comerciais e de serviços para as quais elas fornecem insumos. Rigorosamente, isso implica nada menos do que exigir que os extratores se transformem em algo "além" de extratores. Não é coisa pouca. No entanto, será apenas com essas ligações que uma renda monetária significativa será gerada para as comunidades extrativistas. Transporte, processamento primário, transformação industrial, venda, marketing e desenvolvimento de produtos devem ser incluídos no campo de atividade das reservas, direta ou indiretamente (através de parcerias). Só assim o extrativismo se erguerá acima dos patamares de subsistência e se fortalecerá, pelo menos em algum grau, com a renda monetária gerada por atividades que competem com ele ou que se apropriam a baixos preços dos seus produtos. Se o extrativismo não se sustentar no mercado e se não gerar bons níveis de vida, ele será deslocado pela domesticação, e/ou pela substituição, e/ou "sintetização" dos seus produtos, e/ou pela simples desistência dos extratores.

(v) A expressão "base comunitária" precisa ser mais do que um chavão, embora infelizmente muitas vezes seja usada dessa forma pelos seus proponentes. Trata-se de um qualificativo crucial para distinguir um extrativismo "autônomo" do velho mas persistente - sistema de "aviamento", que por tanto tempo organizou (e em alguns setores continua a organizar) o trabalho dos coletores florestais da Amazônia e de outros lugares. O aviamento foi ou é praticado por um sem-número de intermediários comerciais e financeiros. Esse papel foi assumido diretamente até pelo governo federal (nos tempos do Estado Novo, de Getúlio Vargas), que usou recursos públicos para arregimentar milhares de "soldados da borracha" para reativar seringais abandonados desde a década de 1910. O sistema de aviamento consiste em arregimentar grande número de extratores, colocá-los em situação de isolamento geográfico e social, provocar deliberadamente o seu endividamento, colher a sua produção a preços irrisórios ou em forma de escambo, e assim "prender" os extratores ao sistema. Em inglês, o aviamento tem um nome mais explícito - debt peonage, livremente traduzível como "subordinação pela dívida". As persistentes dificuldades de comunicação e transporte na região amazônica continuam oferecendo condições propícias para o aviamento, com campo livre para atuação do seu personagem mais visível, o ribeirinho "regatão" (dono de barco de suprimentos e compras), ou do seu herdeiro moderno, o "caminhoneiro", que compra produtos à beira das estradas para revenda. O uso de "base comunitária" para o extrativismo não elimina necessariamente as figuras dos financiadores e intermediários, pois que extratores que produzam para o mercado precisam de financiamento e intermediação. O desafio é escapar do modelo tradicional de financiamento e intermediação, $\mathrm{o}$ aviamento.

Para além da questão da viabilidade, as três razões pelas quais consideramos as reservas e as economias extrativistas desejáveis são as seguintes:

(i) do ponto de vista do pluralismo cultural e político, um setor extrativista saudável permitirá a sobrevivência e a cidadania plena de grupos sociais específicos dentro da população rural amazônica e de outras regiões;

(ii) em termos da política fundiária nacional, as reservas extrativistas amazônicas representam uma variante de reforma agrária que se antecipou à primeira grande onda de reforma agrária/colonização no Brasil, em curso, iniciada aproximadamente em 1995. Além disso, o formato da reserva extrativista está se mostrando adaptável a outras regiões e aos seus respectivos grupos de extratores;

(iii) do ponto de vista da racionalidade econômica moderna, parece-nos que grandes extensões de terras florestadas amazônicas são mais bem usadas 
sob um modo extrativista de produção, inclusive por seus efeitos menos impactantes sobre a integridade ecológica, sobre a biodiversidade e sobre as paisagens regionais. Embora o extrativismo de baixa tecnologia seja um modo de produzir que incorpora poucas tecnologias modernas, nem por isso ele é uma forma irracional de exploração dos recursos naturais amazônicos e de outras regiões que retêm as suas floras e faunas originais.

Em suma, o extrativismo pode continuar a existir como uma forma distinta de vida para habitantes de muitas partes da Amazônia brasileira e de outras regiões brasileiras, contribuindo com valores econômicos, ambientais e culturais para o bem-estar dos seus praticantes. Com planejamento e zoneamento adequados, as pessoas e os bens naturais das áreas dedicadas ao extrativismo podem conviver, em escala macrorregional, com formas mais impactantes de uso de recursos. Embora a preservação das florestas amazônicas e de outras

\section{Referências}

Afonso, S. R. Análise socioeconômica da produção de não madeireiros no Cerrado brasileiro e o caso da cooperativa de pequi em Japonvar, MG. Brasília, DF, Dissertação (Mestrado em Ciências Florestais) - Departamento de Engenharia Florestal, Universidade de Brasília, 2008. Brasília, DF: Publicação PGEFL - 086/2008.

Afonso, S. R. A politica pública de incentivo à estruturação da cadeia produtiva do pequi (Caryocar brasiliense). Brasília, DF, Tese (Doutorado em Ciências Florestais) - Departamento de Engenharia Florestal, Universidade de Brasília, 2012. Brasília, DF: Publicação PPGEFL. TD - 024/2012.

Aguiar, F. F. A.; Pinho, R. A. Pau-brasil. Cesalpinia echinata Lam. Árvore nacional. São Paulo, 2007. Disponível em: $<$ http://www.pau.brasil.nom.br/PAU_BRASIL_2007_francismar.pdf>. Acesso em: 14 set. 2014. floras regionais nativas seja um objetivo complexo e sujeito a debates acalorados, a verdade é que no mundo moderno e contemporâneo nenhum trecho de floresta habitado por povos nativos ou residentes desapareceu antes que esses povos fossem removidos, subjugados ou extintos. A presença dos coletores, principalmente quando organizados em suas reservas extrativistas e similares, é parte importante de uma política mais abrangente de preservação e conservação das florestas amazônicas.

\section{Agradecimentos}

Os autores agradecem o apoio recebido pelo Conselho Nacional de Desenvolvimento Científico e Tecnológico e pela Coordenação de Aperfeiçoamento do Pessoal de Nível Superior. São gratos também aos pareceristas anônimos escolhidos por Desenvolvimento e Meio Ambiente para avaliar o presente texto.

Allegretti, M. H. Reservas extrativistas: uma proposta de desenvolvimento da Floresta Amazônica. Curitiba: Instituto de Estudos Amazônicos, 1987. [mimeo]

Allegretti, M. H. A construção social de políticas públicas. Chico Mendes e o movimento dos seringueiros. Desenvolvimento e Meio Ambiente, 18, 39-59, 2008.

Almeida, R. H. C.; Tourinho, M. M. Empresas de biocosméticos, comunidades e o uso dos recursos naturais da Amazônia: uma análise do caso da priprioca (Cyperus articulatus) em Boa Vista Acará, no Estado do Pará. Anais do $1{ }^{\circ}$ Simpósio de Cadeias Produtivas e Desenvolvimento Sustentável na Amazônia e do $9^{\circ}$ Seminário Anual de Iniciação Científica e $3^{\circ}$ Seminário de Pesquisa da UFRA. Belém, outubro de 2011. Disponível em: <http://www.proped.ufra.edu.br/attachments/085_EMPRESAS\%20DE\%20 BIOCOSM $\%$ C $3 \% 89$ TICOS, $\% \overline{2} 0$ COMUNIDADES $\% 20$ 
E\%200\%20USO \%20DOS\%20RECURSOS.pdf $>$. Acesso em: 14 set. 2014.

Alvim, P. de T. Agricultura apropriada para uso contínuo dos solos da Região Amazônica. Espaço, Ambiente e Planejamento, 2(11), 3-71, 1990.

Anderson, A. B. (Ed.). Alternatives to Deforestation in Amazonia: Towards Sustainable Development. New York: Columbia University Press, 1990.

Anderson, A. B.; Posey, D. Manejo de cerrado pelos índios Kayapó. Boletim do Museu Paraense Emílio Goeldi, Série Botânica, 2(1), 77-98, 1985.

Anderson, A. B.; Clay, J. W. (Orgs.). Esverdeando a Amazônia: comunidades e empresas em busca de práticas para negócios sustentáveis. São Paulo: Instituto Internacional de Educação do Brasil, 2002.

Anderson, A. B. et al. O destino da floresta: reservas extrativistas e o desenvolvimento sustentável na Amazônia. Rio de Janeiro: Relume-Dumará; Curitiba: Instituto de Estudos Amazônicos e Ambientais e Fundação Konrad Adenauer, 1994.

Araújo, V. F. de et al. Plantas da Amazônia para Produção Cosmética: uma abordagem química - 60 espécies do extrativismo florestal não madeireiro da Amazônia. Brasília, 2005. Disponível em: <http://www.itto.int/files/itto_project_db_input/2202/ Technical $/ 2.2 \% 20 \mathrm{Plantas} \% 20 \mathrm{da} \% 20 \mathrm{Amaz} \% \mathrm{C} 3 \% \mathrm{~B} 4$ nia $\% 20$ para $\% 20$ produ $\% \mathrm{C} 3 \% \mathrm{~A} 7 \% \mathrm{C} 3 \% \mathrm{~A} 3 \mathrm{o} \% 20$ cosm $\% \mathrm{C} 3 \% \mathrm{~A} 9$ tica. pdf $>$. Acesso em: 7 set. 2014.

Bellwood, P. First farmers: the origins of agricultural societies. Oxford: Blackwell, 2005.

Brito, S. de S. (Ed.). Desafio amazônico: o futuro da civilização dos trópicos. Brasília: Universidade de Brasília/ CNPq, 1990.

Bueno, E. et al. Pau-brasil. São Paulo: Axis Mundi, 2002.

Bunker, S. G. Modes of Extraction, Unequal Exchange and the Progressive Underdevelopment of an Extreme Periphery - the Brazilian Amazon, 1600-1980. American Journal of Sociology, 89(5), 1017-1064, 1984.

Bunker, S. G. Underdeveloping the Amazon. Chicago: University of Chicago Press, 1985.

Castro, C. Gestão florestal no Brasil Colônia. Brasília, Tese (Doutorado em Desenvolvimento Sustentável) - Centro de
Desenvolvimento Sustentável, Universidade de Brasília, 2002.

Castro, J. M. F. de. A selva. 8. ed. Lisboa: Guimarães \& Cia. Editores, 1943.

Cerqueira, E. B.; Gomes, J. M. A.; Silva, M. S. da. Política de garantia de preços mínimos e preservação na cadeia produtiva da cera de carnaúba. Informe Gepec, 15(1), 6481, 2011.

CIFlorestas. Cinco anos do CIFlorestas revelam um setor florestal dinâmico e flexivel em tempos de prosperidade ou crise. Março de 2013. Disponível em: <http://www.bibliotecaflorestal.ufv.br/bitstream/handle/123456789/3304/ AnaliseConjuntural_Numero_40_Ano5.pdf?sequence $=1>$. Acesso em: 11 set. 2014.

CONAB. Proposta de Preços Mínimos Safra 2013/2014 (produtos de inverno, regionais e leite). Brasília: Superintendência de Gestão da Oferta, jan. 2013.

Costa, F. de A. Grande capital e agricultura na Amazônia: a experiência de Ford no Tapajós. Belém: Editora Universitária da UFPA, 1993.

Costa, K. S. Templos de Tânatos, templos de Eros: a exploração da tartaruga nas praias amazônicas. In: Franco, J. L. de A.; Silva, S. D. e; Drummond, J. A.; Tavares, G. G. (Orgs.). História Ambiental: fronteiras, recursos naturais e conservação da natureza. Rio de Janeiro: Garamond, 2012. p. 261-292.

Damasceno, E. M; S. de L. Associativismo, desenvolvimento endógeno e formação da cadeia produtiva do açai em Igarapé-Miri: um estudo de caso. Belém, Dissertação (Mestrado em Planejamento do Desenvolvimento) - Núcleo de Altos Estudos Amazônicos, UFPA, 2009.

De Antoni, G. O Programa Piloto para Proteção das Florestas Tropicais do Brasil (PPG-7) e a globalização da Amazônia. Ambiente \& Sociedade, Campinas, XIII(2), 299-313, jul.-dez. 2010. Disponível em: $<$ http://www.scielo. br/pdf/asoc/v13n2/v13n2a06>. Acesso em: 08 mar. 2015.

De Carlo, S.; Drummond, J. A. O Projeto Yawanawá-Aveda de Urucum: uma parceira de negócios em busca da sustentabilidade para uma comunidade indígena na Amazônia brasileira. In: Sayago, D.; Tourrand, J. F.; Bursztyn, M. (Orgs.). Amazônia: cenas e cenários. Brasília: Editora da Universidade de Brasília, 2004. p. 31-71. 
Dean, W. Brazil and the Struggle for Rubber: A Study in Environmental History. Cambridge: Cambridge University Press, 1987.

Denevan, W. M. The Native Population of the Americas in 1492. Madison: The University of Wisconsin Press, 1992a.

Denevan, W. M. The Pristine Myth: The Landscape of the Americas in 1492. Annals of the Association of American Geographers, 82(3), 369-385, 1992 b.

Denevan, W. M. The "Pristine Myth" Revisited. The Geographical Review, 101(4), 576-591, 2011.

Denevan, W. M.; Padoch, C. (Eds.). Swidden-Fallow Agroforestry in the Peruvian Amazon. Series Advances in Economic Botany, 5. New York: New York Botanical Gardens, 1988.

Diakosawas, D.; Scandizzo, P. Trends in the Terms of Trade of Primary Commodities, 1900-1982: The Controversy and its Origin. Economic Development and Cultural Change, 39(2), 231-264, January 1991.

Dolin, E. J. Fur, Fortune and Empire: the epic history of the fur trade in America. New York: Norton, 2010.

Drummond, J. A. A extração sustentável de produtos florestais na Amazônia brasileira. Estudos Sociedade e Agricultura, 6, 115-137, 1996. Disponível em: <http://r1.ufrrj. br/esa/V2/ojs/index.php/esa/article/view/88>

Drummond, J. A. O manejo agroflorestal científico como um uso alternativo de recursos naturais na Amazônia Brasileira. Estudos Sociedade e Agricultura, 11, 99-133, 1998. Disponível em: <http://r1.ufrrj.br/esa/V2/ojs/index.php/esa/ article/viewFile/137/133>

Drummond, J. A. Recursos naturais, meio ambiente e desenvolvimento na Amazônia brasileira: um debate multidimensional (ensaio bibliográfico). História, Ciências, Saúde-Manguinhos, VI(9), 1135-1177, 2000.

Drummond, J. A. Natureza rica, povos pobres? Questões conceituais e analíticas sobre o papel dos recursos naturais na prosperidade contemporânea. Ambiente \& Sociedade, 10, 1-24, 2002.

Drummond, J. A. Os recursos das florestas tropicais úmidas: usos, usuários e perspectivas de preservação e sustentabilidade. 2013. Disponível em: <https://www. academia.edu/3535047/Os Recursos das Florestas Tropicais_\%C3\%9Amidas_-_Usos_Usu $\%$ C $3 \%$ A 1 rios_e
Perspectivas_de_Preserva\%C3\%A7\%C3\%A3o_e_Sustentabilidade>. Acesso em: 29 dez. 2014.

Duke, J. Tropical Botanical Extractives. Lecture delivered at the Symposium on Rain Forest Conservation. Panama, June 1991. p. 18-21.

Eloy, L.; Toni, F.; Coudel, E. (Eds.). Implementando Pagamentos por Serviços Ambientais no Brasil: caminhos para uma reflexão crítica. Sustentabilidade em Debate, 4(1), 2013.

Enriquez, G.; Silva, M. A.; Cabral, E. (Orgs.). Biodiversidade da Amazônia: usos potenciais dos mais importantes produtos naturais do país. Belém: NUMA/UFPa, 2003.

Enriquez, G.; Barros, W.; Becker, B.; Mendes, C. I. C. Amazônia: rede de inovação de dermocosméticos. Parcerias Estratégicas, 14, 51-118, 2009.

Fearnside, P. M. Extractive Reserves in Brazilian Amazonia. Bioscience, 39(6), 387-393, 1989.

Fernandez, F. A. dos S.; Araújo, B. B. A. As primeiras fronteiras: impactos ecológicos da expansão humana pelo mundo. In: Franco, J. L. de A.; Silva, S. D. e; Drummond, J. A.; Tavares, G. G. (Orgs.). História Ambiental: fronteiras, recursos naturais e conservação da natureza. Rio de Janeiro: Garamond, 2012. p. 97-118.

Ferreira, L. A. Potencial de extração e comercialização do óleo-resina de copaíba (Copaifera spp.): um estudo de caso na Floresta Estadual do Antimary, Acre. Rio Branco (Acre), Dissertação (Mestrado em Ecologia) - Universidade Federal do Acre, 1999.

Fonseca, C. A. G. de M. da; Drummond, J. A. The Payments for Environmental Services Program in Costa Rica: an Assessment of the Program's Early Years. Desenvolvimento e Meio Ambiente, 33, 63-80, 2015.

Foresta, R. A. Amazon conservation in the age of development: the limits of providence. Gainesville: University of Florida Press, 1991.

Freudenburg, W. R. Addictive Economies. Rural Sociology, 57(3), 305-332, 1992.

Fusco, C. A fórmula secreta: a paulista Chemyunion se especializou em explorar a biodiversidade brasileira e hoje exporta conhecimento para os maiores fabricantes mundiais de cosméticos. Exame, 17 de fevereiro de 2010. 
Gonçalo, J. E. Gestão e comercialização de produtos florestais não madeireiros (PFNM) da biodiversidade no Brasil. Anais do XXVI ENEGEP, Fortaleza, Ceará, outubro de 2006. Disponível em: <http://www.abepro.org.br/ biblioteca/ENEGEP2006_TR520346_8257.pdf>. Acesso em: 06 set. 2014.

Grandin, G. Fordlandia: The Rise and Fall of Henry Ford's Forgotten Jungle City. New York: Henry Holt, 2009.

Hecht, S. B.; Cockburn, A. Fate of the Forest. London: Verso, 1989.

Hemming, J. Tree of Rivers: the story of the Amazon. London: Thames \& Hudson, 2008.

Hirschman, A. O. The Strategy of Economic Development. New Haven, Connecticut: Yale University Press, 1958.

Homma, A. K. O. Extrativismo vegetal na Amazônia: limites e oportunidades. Brasília: EMBRAPA - SPI, 1993.

Homma, A. K. O. O extrativismo do óleo essencial de pau-rosa na Amazônia. Paper apresentado no XLIII Congresso da Sociedade Brasileira de Economia e Sociologia Rural - SOBER. Ribeirão Preto, julho de 2005a. Disponível em: $<$ http://www.sober.org.br/palestra/2/141.pdf > . Acesso em: 14 set. 2014.

Homma, A. K. O. Amazônia: como aproveitar os benefícios da destruição? Estudos Avançados, 19(54), 2005b. Disponível em: <http://www.scielo.br/pdf/ea/v19n54/06.pdf>

Homma, A. K. O. Biodiversidade e biopirataria na Amazônia: como reduzir os riscos? Passages de Paris, 6, 111-128, 2011. Disponível em: <http://www.alice.cnptia.embrapa.br/ handle/doc/954896>

Homma, A. K. O. Extrativismo vegetal ou plantio: qual a opção para a Amazônia? Estudos Avançados, 26(74), 2012. Disponível em: $<\mathrm{http} / /$ www.scielo.br/scielo.php?script=sci_ arttext\&pid=S0103-40142012000100012\&lng=pt\&nrm $=$ iso $>$

Homma, A. K. O.; Nogueira, O. L.; Menezes, A. J. E. A. de; Carvalho, J. E. U. de; Nicoli, C. M. L.; Matos, G. B. de. Açaí: novos desafios e tendências. Amazônia: Ciência \& Desenvolvimento, 1(2), 2006.

Humphries, S.; Holmes, T. P.; Kainer, K.; Koury, C. G. G.; Cruz, E.; Rocha, R. de M. Are community-based forest enterprises in the tropics financially viable? Case studies from the Brazilian Amazon. Ecological Economics, 77, 62-73, 2012.

IAC - Instituto Agronômico de Campinas. A importância da borracha natural. Disponível em: <http://www.iac. sp.gov.br/areasdepesquisa/seringueira/importancia.php>. Acesso em: 21 mar. 2015.

IBGE - Instituto Brasileiro de Geografia e Estatística. Produção da Extração Vegetal e da Silvicultura - PEVS. v. 28, 2013. Rio de Janeiro, 2014.

INCRA - Instituto Nacional de Colonização e Reforma Agrária. Boletim de Análise sobre o Desmatamento em Assentamentos na Amazônia. Brasília, agosto de 2014.

INCRA - Instituto Nacional de Colonização e Reforma Agrária. Relatório Geral com as Modalidades de PAs. Documento enviado em 17 de março de 2015 por e-mail por Elizabeth Fonseca, Chefe da Divisão de Criação e Implantação de Projetos de Assentamentos (DTI-2) do INCRA. 2014. Disponível em: <http://www.incra.gov.br/images/ reforma_agraria/projetos_e_programas/relacao_beneficiarios/sr01_pa.pdf>. Acesso em: 21 ago. 2015.

Jackson, J. The Thief at the End of the World: rubber, empire and the obsessions of Henry Wickham. London: Duckworth, 2008.

Kitamura, P. C. A Amazônia e o desenvolvimento sustentável. Brasília: Embrapa, 1994.

Le Tourneau, F.-M.; Bursztyn, M. Assentamentos rurais na Amazônia: contradições entre a política agrária e a política ambiental. Ambiente \& Sociedade, XIII(1), 111-130, 2010.

Lins, L. C. G. Proposta de inclusão de variáveis na produção da extração vegetal e da silvicultura. Rio de Janeiro, Gerência de Silvicultura e Extração Vegetal - GESEV; Diretoria de Pesquisas, IBGE, novembro de 2013. Disponível em: $<$ http:// www.ibge.gov.br/home/estatistica/indicadores/prpa/Inclusao de_variaveis_PEVS_2013.pdf>. Acesso em: $01 \mathrm{dez} .2014$.

Maciel, R. C. G.; Reydon, B. P.; Sales, J. A. da C.; Oliveira, G. de. Pagando pelos Serviços Ambientais: uma proposta para a Reserva Extrativista Chico Mendes. Acta Amazônica, 40(3), 489-498, 2010. Disponível em: <http://www.scielo. br/pdf/aa/v40n3/07.pdf>

Martin, C. Keepers of the Game: Indian-animal relationships and the fur trade. Berkeley: University of California Press, 1978. 
Mazoyer, M.; Rodart, L. História das agriculturas no mundo: do Neolítico à crise contemporânea. São Paulo: Editora da UNESP; Brasília: NEAD, 2010.

Meggers, B. J. Amazonia: Man and Culture in a Counterfeit Paradise. Arlington Heights, Illinois: Harlan Davidson, 1971.

Miller, S. An Environmental History of Latin America. Cambridge: Cambridge University Press, 2007.

Moran, E. F. Developing the Amazon. Bloomington: Indiana University Press, 1981.

Moran, E. F. A Ecologia Humana das populações da Amazônia. Petrópolis: Vozes, 1990.

Müller, I. Anuário Brasileiro do Cacau 2012. Santa Cruz do Sul: Editora Gazeta Santa Cruz, 2012.

Myers, N. A Wealth of Species: Storehouse for Human Welfare. Boulder, Colorado: Westview Press, 1983.

Myers, N. The Primary Source: Tropical Forests and our Future. New York: Norton, 1985.

Negret, F. Brasil: compensação de serviços ambientais aos agricultores familiares. 2008. Disponível em: $<\mathrm{http}: / / \mathrm{www}$. adital.com.br/site/noticia.asp?lang=PT\& $\operatorname{cod}=28063>$. Acesso em: 10 mar. 2015.

Peters, C. M.; Gentry, A.; Mendelsohn, R. O. Valuation of an Amazonian Rainforest. Nature, 339(29), 655-656, 1989.

Ponte, K. F. da; Thomaz Junior, A. Os desdobramentos da crise estrutural do capital no estado do Acre: alguns apontamentos sobre trabalho e "sustentabilidade". Revista OKARA: Geografia em Debate, 6(1), 109-121, 2012.

Porto-Gonçalves, C. W. Natureza e sociedade: elementos para uma ética da sustentabilidade. In: Quintas, J. S. (Org.). Pensando e praticando a educação ambiental na gestão do meio ambiente. Brasília: Ibama, 2000. p. 49-76. (Coleção Meio Ambiente, n. 3)

Posey, D. A.; Balee, W. (Eds.). Resource Management in Amazonia: Indigenous and Folk Strategies. Bronx, New York: New York Botanical Garden, 1989.

Prebisch, R. The Economic Development of Latin America and its Principal Problems. New York: United Nations, 1950.

Rocha, S. Pobreza no Brasil: afinal, de que se trata? Rio de Janeiro: Editora FGV, 2003.
Roosevelt, A. The Development of Prehistoric Complex Societies: Amazonia, a Tropical Forest. In: Bacus, E. A.; Lucero, L. J.; Allen, J. (Eds.). Complex Polities in the Ancient Tropical World. Arlington: American Anthropological Association, 1999a. p. 13-34.

Roosevelt, A. Twelve Thousand Years of Human-Environment Interaction in the Amazon Floodplain. Advances in Economic Botany, New York, New York Botanical Garden, 13, 371-392, 1999b.

Salomão, R. de P.; Rosa, N. A.; Castilho, A.; Morais, K. A. C. Castanheira-do-brasil: recuperando áreas degradadas e provendo alimento e renda para comunidades da Amazônia Setentrional. Boletim do Museu Paraense Emílio Goeldi. Ciências Naturais, Belém, 1(2), 65-78, 2006. Disponível em: <http://scielo.iec.pa.gov.br/pdf/bmpegcn/v1n2/ v1n2a05.pdf $>$

Sampaio, P. T. B.; Ferraz, I. D. K.; Camargo, J. L. C. Manual de Sementes da Amazônia - Pau-rosa (Aniba rosaeodora Ducke) Lauraceae. Manaus, Instituto Nacional de Pesquisas da Amazônia (INPA). Fascículo 3. 2000. Disponível em: <https://www.inpa.gov.br/sementes/manuais/fasciculo3_aniba.pdf>. Acesso em: 14 set. 2014.

Schmink, M.; Wood, C. (Eds.). Frontier Expansion in Amazonia. Gainesville: University of Florida Press, 1984.

Schmink, M.; Wood, C. Contested Frontiers in Amazonia. New York: Columbia University Press, 1992.

Serigati, F. Fundamentos x mercados financeiros. Preços agrícolas. Revista Agroanalysis, agosto 2012. Disponível em: <http://www.agroanalysis.com.br/materia_detalhe. php?idMateria=1314>. Acesso em: 14 set. 2014.

Silva, A. C. G. da; Silva, J. da C. Seringueiros na Amazônia. Paper apresentado no II Colóquio Nacional do NEER. Novembro de 2006. Curitiba, Paraná. Disponível em: $<$ http://www.neer.com.br/anais/NEER-2/Trabalhos_NEER/ Ordemalfabetica/Microsoft $\% 20$ Word\%20-\%20AntonioCarlosGalvaodaSilva.ED2V.pdf>. Acesso em: 09 abr. 2015.

Silva, R. G.; Teixeira, E. C. A abordagem microeconômica da política de subsídios à borracha natural do Acre. Paper apresentado no XLII Congresso da Sociedade Brasileira de Economia e Sociologia Rural. Cuiabá, Mato Grosso, 2004. Disponível em: <http://www.sober.org.br/ palestra/12/06O367.pdf>. Acesso em: 14 set. 2014. 
Steward, J. Handbook of South American Indians. 7 volumes. Washington, D.C.: Smithsonian Institution, 1946-1959.

Tavares, M. F. de F.; Fischer, T. B.; Tonettel, R. Agregação de valor na castanha do Brasil: o caso da Natura Ekos. Central de Cases. ESPM. Março de 2010. Disponível em: <http://www.espm.br/Publicacoes/CentralDeCases/ Documents/NATURA_LINHAEKOS.pdf $>$. Acesso em: 10 mar. 2015.

Tfouni, S. A. V.; Camargo, M. C. R.; Vitorino, S. H. P.; Menegário, T. F.; Toledo, M. C. de F. Contribuição do guaraná em pó (Paullinia cupana) como fonte de cafeína na dieta. Revista de Nutrição, 20(1), 63-68, 2007.

Topik, S.; Marichal, C.; Frank, Z. From Silver to Cocaine: Latin American Commodity Chains and the Building of the World Economy, 1500-2000. Durham: Duke University Press, 2006.

Uhl, C.; Vieira, I. Ecological impacts of selective logging in the Brazilian Amazon: a case study from the Paragominas region of the state of Pará. Biotropica, 21, 98-106, 1989.

Uhl, C.; Barreto, P.; Veríssimo, A.; Vidal, E.; Amaral, P.; Barros, A. C.; Souza Jr., C.; Johns, J.; Gerwing, J. Natural Resource Management in the Brazilian Amazon. BioScience, 47, 160-168, 1997.

Veríssimo, A.; Barreto, P.; Mattos, M.; Tarifa, R.; Uhl, C. Impactos da atividade madeireira e perspectivas para $\mathrm{O}$ manejo sustentável da floresta numa velha fronteira da Amazônia: o caso de Paragominas. In: Barros, A.; Veríssimo, A. (Orgs.) A expansão madeireira na Amazônia: impactos e perspectivas para o desenvolvimento sustentável do Pará. Belém: Imazon, 2002.

Vilhena, M. R. Uso econômico da biodiversidade na região sul do estado do Amapá: o Programa Castanha do Brasil na Cooperativa Mista de Produtores e Extrativistas do rio Iratapuru (COMARU). Macapá, Amapá, Governo do Estado do Amapá, agosto de 2001. Disponível em: <www.ecoeco. org.br/conteudo/publicacoes/encontros/quarto_en/mesa5/8. pdf $>$. Acesso em: 10 mar. 2015.

Young, A. M. The Chocolate Tree: A Natural History of Cacao. Revised and expanded edition. Gainesville: University Press of Florida, 2007.

Wallerstein, I. The Modern World-System, vol. I: Capitalist Agriculture and the Origins of the European WorldEconomy in the Sixteenth Century. New York: Academic Press, 1974.

Wallerstein, I. The Modern World-System, vol. II: Mercantilism and the Consolidation of the European World-Economy, 1600-1750. New York: Academic Press, 1980.

Wallerstein, I. The Modern World-System, vol. III: The Second Great Expansion of the Capitalist World-Economy, 1730-1840's. San Diego: Academic Press, 1989. 